\title{
TRADICIJSKA PREHRANA I PREHRAMBENA KULTURA
}

\author{
Jasmina JURKOVIĆ \\ Gradski muzej Virovitica \\ Dvorac Pejačević \\ 33000 Virovitica
}

\begin{abstract}
Prehrana ima osobito važnu ulogu u društvenome životu. Zajednički obroci predstavljaju središte društvenih odnosa.
\end{abstract}

(Visočnik 2004:22)

\section{UVOD}

$\mathrm{T}$ radicijska prehrana tema je mnogih etnoloških istraživanja i radova. U domaćoj literaturi najčešće je zastupljeno obrađivanje prehrane ruralnog stanovništva kao marljivoga prikupljanja te opisivanja regionalnih osobitosti u načinu uzgoja pojedinih biljaka, pripravljanju jela i konzumiranju hrane u periodu od kraja 19. stoljeća do polovice 20. stoljeća . ${ }^{1}$ Teorijske studije o hrani kao sredstvu izražavanja identiteta grupe te odnosa prema susjednim grupama još uvijek su zastupljenije u svjetskoj nego domaćoj literaturi. ${ }^{2}$ Osobitosti određene skupine, važne za razumijevanje identiteta, definiraju se kao "markeri”, obilježja koja bi pripadnici prepoznavali i pamtili kao razlikovne elemente i simbole identiteta u odnosu na osobitosti drugih skupina (usp. Bromberger et al. 2002: 182). Oni se dijele na one koji se oslanjaju na objektivna obilježja i na one koji počivaju na subjektivnoj želji za razlikovanjem (usp. Čapo Žmegač 1997: 72).

Terenskim istraživanjem teme tradicijska prehrana, provedenim na području Krivoga Puta ${ }^{3}$, prikupila sam detaljne podatke o osobitostima u prehrani primorskih Bunjevaca i načinu pripravljanja hrane. Osobitosti, kojima se pojedinci opredjeljuju za pripadnost, izdvojili su sami kazivači, a predstavljaju jedan od čimbenika autoidentifikacije primorsko-bunjevačke skupine u odnosu na najbližu urbanu sredinu, stanovništvo grada Senja. Način odijevanja (narodna nošnja, obrada tekstila), gospodarska specifičnost (privreda, prehrana) i govor kategorije su koje pripadnici primorsko-bunjevačke skupine izdvajaju kao obilježja raspoznavanja od urbane skupine stanovništva (usp. Šrbić Alempijević 2003, 427). Elementi unutar tih kategorija, koje pripadnici odaberu kao važne za svoju etničnost, ne predstavljaju kulturnu cjelovitost jer su oni trenutni izbor, te podliježu mijenjanju (usp. Grbić 1994, 29).

Cilj ovoga rada je, na temelju sustavno prikupljene građe, ustanoviti koji segmenti čine tradicijsku prehranu te time omogućuju autoidentifikaciju bunjevačke zajednice i shvaćanje njihovih razlikovnih obilježja u odnosu na najbližu zajednicu, na građane Senja. Spomenut će se i odnos prema drugim zajednicama, Ličanima i Slavoncima, koji je u manjoj mjeri naglašen unatoč povezivanju kroz razmjene namirnica i dobara na sajmovima. Također, radom se žele prikazati namirnice i jela koja, prema shvaćanjima kazivača, predstavljaju tradicijsku prehranu oblikovanu generacijama i uvriježenu u njihovoj zajednici, kao i neki od načina privređivanja ruralnoga stanovništva. Poseban dio rada posvećen je tradicijskoj prehrani u suvremenom životu i iskazivanju gostoprimstva.

Takvi radovi odraz su etnologije koja se razvijala pod utjecajem Radićeva upitnika Osnova za sabiranje i proućavanje grade o narodnom životu iz 1897, pa su osobitost velikih monografija (primjerice Lovretić: Otok, Ivanišević: Poljica, Lang: Samobor i dr.), ali i zasebnih radova poput M. Randić: Prehrana, Etnološka istraživanja 6., Zagreb, 1999. i sl.

2 Poseban pregled svjetskih etnoloških doprinosa vidjeti kod S. Menneli et al., 1998, 35-41.

3 Istraživanje na Krivome Putu obuhvatilo je područja Podbila, Alana, Krivoga Puta, Mrzlog Dola, Francikovca i Veljuna Primorskog, te njihovih zaseoka. 
Potaknuta oskudnim podacima i manjkavom građom o prehrani Krivopućana u senjskome zaleđu, započela sam sustavno obrađivanje ove teme. U tu svrhu izradila sam upitnicu koja se tijekom istraživanja nadopunjavala pitanjima i lokalnim nazivima. ${ }^{4} \mathrm{U}$ terenskim ispitivanjima služila sam se metodom strukturiranoga intervjua, gdje sam od kazivača nastojala doznati konkretne odgovore na ciljana pitanja prema upitnici, i nestruktuiranog koji je uključivao razgovor o pojedinačnim životnim pričama i kritičkim osvrtima na njihovu prehranu. Percepcija vremena u određivanju nekada pojedinačno je varirala, a uvjetovana je ponajprije godištem kazivača. ${ }^{5}$ Dobiveni podaci odnosili su se pretežito na razdoblje od tridesetih godina 20. stoljeća do vremena istraživanja, početka 21. stoljeća. Nadalje, pripadnici ove skupine su valorizirali svoju sadašnju prehranu (vrijeme istraživanja), s onom "iz sjećanja” što se većinom odnosilo na razdoblje prije Drugoga svjetskog rata.

Ispitivanjem obuhvaćeni lokaliteti znatno su depopulirani. Masovno iseljavanje Krivopućana u gradove bilo je sredinom 20. stoljeća. Više nije bilo zarade tu, sve se okrenilo u grad jer nije bilo posla. ${ }^{6} \mathrm{U}$ vrijeme ispitivanja područje Krivoga puta znatno je iseljeno, pa se tako u pojedinim lokalitetima moglo pronaći samo jedan ili nekolicina kazivača starije životne dobi. Zahvaljujući vremenu ispitivanja (lipanj) većina pripadnika ove skupine odmarala se na svježijoj klimi Krivoga Puta od one u gradu, pa su intervjui provođeni u naseljima iz kojih potječu.

Temom prehrane kod primorskih Bunjevaca, bavila se jedino etnologinja Marija Friščić u članku "Teme iz materijalne i duhovne kulture primorskih Bunjevaca", te u prilogu "Proizvodnja sira kod primorskih Bunjevaca”. 7 U prvom radu, među ostalim temama, autorica iznosi kratki pregled mliječnih proizvoda te opise njihova pripravljanja, dok u drugome donosi prikaz priprave sira škripavca potkrijepljen kazivanjima s terenskih ispitivanja. Podaci iz ovih radova shvaćeni su kao polazna osnova za nadogradnju prikaza tradicijske prehrane primorskih Bunjevaca, te kao etnografska građa pogodna za usporedbu s vlastitim podacima, unatoč različitim zaseocima i lokalitetima koje smo istraživanjima obuhvatile. ${ }^{8}$

Kroz prikaz života dviju zadruga s područja Krivoga Puta, etnologinja Milana Černelić donosi i podatke o namirnicama i pripremi mliječnih proizvoda, kao i svakodnevnim obrocima. ${ }^{9}$ Iako se u ovome prilogu ne bavi prehranom, kroz prikaz imovina, gospodarenja, organizacije obiteljskoga života i diobe dviju zadruga, mjestimični podaci o prehrani osobito su korisni kao potvrda već prikupljene etnografske građe o primorskim Bunjevcima. Podaci su prikupljeni 1981. stoga mogu biti relevantan pokazatelj pri definiranju vremenskih odrednica, kao i uspoređivanja s podacima prikupljenim početkom 21. stoljeća.

Monografija "Kompolje, narodni život i običaji” autora Jure Grčevića, donosi vrijedne podatke marljivo prikupljene za selo u Gackoj dolini, a prema Radićevoj Osnovi. Unatoč tome što podaci nisu o primorskim Bunjevcima, zbog pripadnosti senjskoga zaleđa i doline Gacke dinarskoj regiji (danas Ličkosenjskoj županiji), važan su pokazatelj tradicijske prehrane oblikovane geografskim karakteristikama vrlo

4 U njezinoj izradi služila sam se Upitnicom Etnološkog Atlasa, Svezak 2, (teme od 62 do 71, te 74.) koja je izrađena za potrebe nekadašnjega Etnološkoga atlasa Jugoslavije Filozofskoga fakulteta Sveučlišta u Zagrebu, 1965.

5 Najstariji ispitani kazivač rođen je 1917. godine, a najmlađi 1948. godine; spol nije bio kriterij odabira kazivača pa su ispitivanjem obuhvaćeni podjednako žene i muškarci.

6 Izvadak iz kazivanja Marije Rončević iz Alana, zabilježenog u lipnju 2003. Više o iseljavanju stanovništva vidi u prilozima o migracijama: autorice Marijete Rajković u prvom svesku Monografije, str. 79-94, i Marijete Rajković i Jasmine Jurković, str. 95-119.

7 Tekst M. Friščić o pripravi sira nalazi se u sklopu članka J. Andrić, 2003, 41-42.

8 Kako i sama autorica obrazlaže u članku, za prvu fazu istraživanja cilj joj je bio iznijeti najvažnije podatke za pojedine teme, a ne cjelokupan prikaz građe. Stoga mi nisu svi, tada prikupljeni, podaci bili dostupni. Lokaliteti koje je obuhvatila terenskim istraživanjem nalaze se na širem području senjskoga zaleđa (Podbilo, Francikovac, Žukalj, Ljubežine, Melnice i Crni Kal).

9 Vidi rad: Černelić 2000. 
sličnih područja. Iako je autor napisao djelo nakon Drugoga svjetskog rata, podaci su prožeti osobnim uspomenama koje ponegdje u građi omogućuju stariju vremensku dataciju. Međutim, dio monografije posvećen hrani (od 105 do 113 stranice) nema određene vremenske odrednice, osim iznimke o sadnji krastavaca (kumara) i rajčice (paradajza) nakon Prvoga svjetskog rata (usp. 2000: 107). Građu je stoga teže promatrati kroz vanjske i unutarnje utjecaje te promjene.

Druga monografija, “Tradicijski život i kultura ličkoga sela Ivčević Kosa” etnologinje Mare Hećimović-Seselj, oslanja se na podatke prikupljene terenskim istraživanjima u razdoblju od 1935. do 1980. Pod naslovom "Hrana i suđe za nju” (od 51. do 66. stranice) autorica naglašava kako je prikupljena građa relevantna za "razdoblje od početka druge polovice 19. stoljeća pa do danas"(1985./op.a.) (usp. 1985:51). Obzirom na konstantne odnose Ličana i primorskih Bunjevaca, ali također i, već spomenutu, geografsku sličnost pojedini podaci mogu poslužiti u kompariranju građe.

Autor Mile Japunčić, koji se posvetio istraživanju povijesnih i etnoloških tema zavičajnoga kraja, u knjizi "Lovinački kraj: vrijeme i ljudi" opisuje neke od tema iz životnih običaja Lovinca naseljenoga, kako ističe: "Lovinačkim Hrvatima, mahom Bunjevcima”. Prehrana, kao zasebna cjelina, nije obrađena. Mjestimični podaci o proizvodima i namirnicama tek su usputno uočljivi kroz opise drugih tema. Tako, primjerice pod naslovom "Poslovi oko blaga" on napominje: Od blaga je čovjek imao mnogostruku korist. Prvenstveno mu je služilo kao hrana: meso i mlijeko iz kojega se proizvodi poznati lički sir škripavac, skorup i razni začini(...) (2000, 317). Unatoč tome, rad valja uvrstiti u građu o Bunjevcima, što i je važna značajka koja predstavlja mogućnost uvida rasprostranjenosti nekih prehrambenih proizvoda, kao i drugih običaja.

Djelomični podaci o prehrani i prehrambenim navikama mogu se iščitati i u knjizi "Bunjevci" autora Rikarda Pavelića. Kroz pretežito romantične opise, moguće je uočiti pojedinačne podatke o prehrambenim namirnicama. Takav je i sljedeći citat: Među koscima, a osobito mladima, razvija se pravo natjecanje tko će više i bolje pokositi livadu. A kakvo je zadovoljstvo u trenutku kada planinka na konju donese bogatu $i$ ukusnu hranu! Tu je i rakije i vina, suhih rebrica i divenice sa zeljom i grahom, pa zatim čuveni bunjevački sir škripavac i krumpir koravac, pa kada se svega toga čovijek naužije na šumskom zraku, nije čudo što mladići prave svakojake ludorije(...)(1973:192).

\section{PRIVREĐIVANJE I PREHRANA PRIMORSKIH BUNJEVACA}

Sakodnevna prehrana ruralnoga stanovništva zavisila je od načina privređivanja. Područje Krivoga $\checkmark$ Puta, prema geografskim obilježjima, spada u krško, vapnenačko područje s bjelogoričnim šumama na višim nadmorskim visinama. (Aralica 2000: 228). Svjesnost geografske osobitosti vlastitoga kraja oslikava u šali Marija Prpić Vinina iz Veljuna: Kod nas je rodilo kamenje jako dobro ove godine. Takva geografska i klimatska obilježja uvjetovala su bavljenje ruralnoga stanovništva određenim privrednim granama, u prvom redu stočarstvom ${ }^{10}$. Ova privredna grana značajno je odredila orijentiranost u prehrani bunjevačkoga stanovništva, što je vidljivo u upotrebi mliječnih proizvoda u pripremanju jela, ali i kod činjenice da su se stanovnici Senja mliječnim proizvodima opskrbljivali na sajmovima i od mljekarica iz Krivoga Puta. ${ }^{11}$ Da su sajmovi predstavljali značajna mjesta susretanja te izmjenjivanja namirnica kao i domaćih proizvoda ovih dviju skupina prisjeća se Tome Špalj Cucin iz Krivoga Puta: Onda su naše ženske išle od tih brda ozgora, sa konjima, nosile su drva, pa su nosile i mlijeka, jaja i vako što bi, napravi sira $i$ vrhnja, masla $i$ tako to $i$ onda otidi tu u grad i donesi kave, cukra, petrolejuma. U takvom tipu privređivanja osobito značajna bila je prodaja mliječnih proizvoda, o kojoj Ivan Krmpotić Bokula iz Veljuna kaže: Svaka kuća imala magarca, a

10 Više o tradicijskom gospodarstvu vidi u prilozima Marijete Rajković u prvom svesku Monografije, str. 157-278.

11 Za podrobnije podatke o sajmovima i trgovini vidi u prilogu Tihane Rubić u prvom svesku Monografije, str. 323352. 
bilo slabo posla pa su žene svaki tjedan jedanput ili dvaput išle u Senj, pa onda mlijeka ovog saberi, ukiseli i usiri. E, onda to na pijac prodavale u Senj. ${ }^{12}$

Uz prevoženje drveta za ogrijev iz zaleđa u grad, kao oblik privređivanja donosio se i led, u pravilu po narudžbama. Pravljenje leda bila je osobitost područja Veljuna, a kako navodi Luka Krmpotić Brnde to je bio posao s koljena na koljeno njegovan u njegovoj obitelji te jedan od načina ekonomske egzistencije. Prvo se iskopa jedna rupa i onda se nabi, da bude ilovača, a onda se snijega natrpa, pa bude snižnjača. Napravi se drveni bat, taj snijeg se izbatira, pa onda pokri sa šušnjom listom i granama. I tako bude led. ${ }^{13}$ Prije uvođenja hladnjaka, sredinom pedesetih godina 20. stoljeća, led je bio potreban u slastičarnama i mesnicama, koje su usluge donošenja leda plaćale novcem. O ekonomskoj isplativosti pravljenja leda, ali i zavisnosti posla o vremenskim prilikama, Mirko Prpić Cungo iz Matić Gaja dodaje: Bog nam je davao sniga, pa smo novce zaradivali.

Osim prema urbanoj sredini, stanovništvo Krivoga Puta otvaralo se komuniciranju i trgovanju i s drugima; povezanost s Ličanima obrazlaže Marko Pavelić Mijatin iz Žuljevića: Bilo je ti švercera, mi kažemo kirci, oni su gonili pa mijenjali gore u Liku. ${ }^{14}$ Trgovanje s Ličanima, osobito u Brinju i Prokikama, potvrđuju svi kazivači.

Nemogućnost privređivanja u ratnom i poratnome razdoblju pridonijela je osiromašenju ovog kraja. Stoga je istraživanje prehrambenih navika izazvalo kod većine kazivača prisjećanje na nepovoljne ekonomske uvjete poratnog razdoblja.

Oskudica u prehrambenim artiklima prisilila je ruralno stanovništvo na učestalost pripremanja skromnijih jela, kao što su jušna: Radili su kašu od zoba kad nije bilo drugoga (...) mogu reći da sam i u nekim momentima bio gladan. ${ }^{15}$ Osobito su se teško nabavljale elementarne namirnice kao cukar (šećer), sol, kava. Šećer se koristio u manjim količinama za pripremanje jela. Kako je činila neizostavan dio jutarnjega obroka, kava se u ekonomski nepovoljnim vremenima pripremala od ječma, koji se stupao u drvenoj stupici; nije bilo bolje, malo je mirišalo na kavu. ${ }^{16}$ Sol se nabavljala u Senju, ali i nosila u Slavoniju kao zamjena, rampaltrampa za druge proizvode (žito, kukruz, kavu i drugo): Za sol ne znam da je ikada bila kriza, samo nije bilo šenice, brašna. Majka je išla, vozili smo sol u Slavoniju za šenicu, tako da smo imali. ${ }^{17}$ Također, sol se nabavljala i od otočana s Paga. Marija Tomljanović Čonina iz Krivoga Puta sjeća se kazivanja svoje majke koja je minjala robu za sol. Kata Prpić Čopićeva iz Francikovca prisjeća se jednog od načina pribavljanja soli: Moj je otac pokojni iša' u Senj po more. Pa dovezi i onda pokojna majka kuvaj i od toga napravi sol, a to nije bijela nego mrka sol. Žitarice su se u ratnome razdoblju mljele ručno na kamenom žrvnju. Luka Krmpotić Brnde iz Veljuna prisjeća se: Onda se to okreći, a treba jaki dečko, i dvoje poneki okretali.

Percepcija o vlastitoj proizvodnji hrane kao manje vrijednoj isticala se tijekom gotovo svih razgovora: Većinom se jela domaća hrana, jer nije bilo novaca da se kupuje. ${ }^{18}$ Sličan stav očitovao se i u kazivanju Mire Tomljanović Ropete iz Krivog Puta: Prehranjivalo se sovim što se imalo, domaće jer nije bilo kupovine. Marko Tomljanović Cote iz Šimerića prisjeća se: Ja sam se veselio kad je moja mati, kad sam bio mali, otišla u Senj i obavezno se moralo iz Senja donjesti kruh, bijeli kruh, senjski čuveni poznati, e imali su vrhunski kruh, bijel, p̌senično brašno. Taj krub kad je donila moja majka, to je bilo, ma kakve torte, to se pojelo u hipu bez ikakvih dodataka, to je bilo veselje.

12 Ovakav način privređivanja među ruralnim stanovništvom Krivoga Puta bio je uobičajen do sedamdesetih godina 20. stoljeća.

13 Citat iz kazivanja Ivana Krmpotića Bokule iz Veljuna. O temi sajmova i prodaje robe na sajmovima vidi općenito u prilogu Tihane Rubić u prvom svesku Monografije, str. 323-352.

14 Naziv kirci odnosi se na stanovništvo naseljeno na području od Novog Vinodolskoga do Rijeke.

15 Ovo je izvadak iz kazivanja Marka Tomljanovića Cote iz Šimerića, zabilježenog u lipnju 2003. godine.

16 Milan Tomljanović Periša, Zamalić.

17 Nada Prpić Terezina, Krivi Put.

18 Kazivanje Katice Hotlovec iz Matić Gaja zabilježeno je u lipnju 2003. 
Uvriježeni stav kako je među ruralnom sredinom bila "prostija” hrana mijenja se tek povećanjem turističke zainteresiranosti za domaće proizvode zadnjeg desetljeća 20. stoljeća. S tim su u vezi i valorizacije kazivača o prehrani nekada i danas. ${ }^{19}$

Izdvaja se i kazivanje Ivice Vukelića Popa iz Rupe: Ako si ima više zemlje bija si jači, ako je kućanstvo imalo puno ljudi, malo zemlje, tu se jako teško živilo, ali tu se nije kupovalo. Stav o vlastitoj hrani kao jednostavnoj i neraznolikoj u namirnicama, očitovao se i tijekom boravka na terenu. Tako Zlata Tomljanović Pešina, s predodžbom o bogatstvu drugih krajeva, kazuje: kod nas baš u Krivom Putu nije bilo nekih običaja ni specijaliteta. ${ }^{20}$ To je naša jako škrta zemlja, a sama hrana koju smo lično proizvodili to nije raznovrsno bilo, ko što ima recimo vuda uz more gdje je malo bolja zemlja (...), to je bilo dosta pasivno, nije bilo obilato kao po Slavoniji i Srijemu. Ovim riječima Tome Špalj Cucin iz Špalja prikazuje siromašnost svoga kraja, ali i jednostavnost u pripravljanju jela. Ipak, u daljnjem razgovoru kazivač donosi podatke koji kazuju suprotno od njegova stava o prehrani. Razgovori s pripadnicima ove skupine pokazuju kako postoje namirnice i jela koja se uspoređuju s drugim skupinama i koje time određuju njihovu vlastitu skupinu. Kroz kazivanje o krumpiru, Marko Pavelić Mijatina iz Žuljevića jasno pravi razliku u kvaliteti proizvoda, te time svoju zajednicu određuje kao "bolju”. On ističe: naš je krumpir kud i kamo kvalitetniji nego vaš, slavonski.

\section{TRADICIJSKA PREHRANA I OBROCI}

$\mathrm{P}$ rehranu Krivopućana od kraja 19. pa do sredine 20. stoljeća karakterizirali su proizvodi domaće proizvodnje te namirnice pribavljane kupnjom u gradu ili razmjenom na sajmovima. ${ }^{21}$ Svakodnevni obroci razlikovali su se sadržajem i količinom s obzirom na godišnja doba i prigode. Kada se govori o razdoblju učestalijih i zahtjevnijih poslova, upotrebljava se naziv ljeto (kako to koriste i kazivači), iako se to često ne podudara kalendarski $s$ razdobljem ljeta. U zimskome se periodu obujam poslova smanjivao. Ljetno doba kazivači određuju prema svakodnevnim gospodarskim poslovima, kao što, primjerice, pojašnjava Ivanka Atalić iz Alana: Počinje koncem četvrtoga mjeseca, kad se počelo orat i sve do desetog mjeseca, dok bi se krumpir okopao, dok bi se drva nabavila i tako. Tako je ljeti zabilježeno pripravljanje pet obroka, a zimi manje - tri. ${ }^{22}$ Podjelu na više obroka ljeti kazivači obrazlažu većom potrebom za snagom, s obzirom na potrebu obavljanja mnogih poslova oko kuće, sa životinjama i u polju. Objašnjenja za redukciju zimskih obroka su: ne mora se toliko rano ni ustajati, kraći je dan pa je bilo dosta ta tri obroka ${ }^{23}$; manje se troši, što više radiš više trošiš ${ }^{24}$. Zimski obroci su: ručak (od sedam do devet sati ujutro), užina (u podne) i večera. Ljeti su to: ručak (između pet i sedam sati ujutro), doruča ${ }^{25}$ ili marenda ${ }^{26}$ ili veliki ruča $k^{27}$ (oko deset sati ujutro), užina ${ }^{28}$ (u podne), mala užina (od šesnaest do osamnaest sati popodne) i večera (do dvadeset i jedan sat). Jedini obrok identičnoga sadržaja za sve navedene lokalitete je ručak. Neizostavna je, prije odlaska na rad,

19 Vidi o tome u dijelu ovoga priloga, u odlomku naslova Današnja prehrana i gostoprimstvo.

20 Osobito je raširen stav o "bogatstvu” Slavonije, koja prema shvaćanjima kazivača obuhvaća teritorij od Karlovca prema unutrašnjosti. Bogatstvo Slavonije definira se shvaćanjima o raznolikijim namirnicama i jelima.

21 Takve općenite karakteristike obilježile su za to razdoblje prehranu Hrvatske, ali i šire (usp. Muraj 1998:101).

22 Isti podaci potvrđeni su i u zadruzi Tomljanović-Puljiz iz Podbila (Panjići), dok se u zadruzi Prpić-Grgajice iz Kosove Buljime spominju četiri obroka (ručak, malu užinu, užinu i večeru) bez navođenja razlika u zimskom i ljetnom razdoblju. Vidi: Černelić 2000:212.

23 Ivica Vukelić Pop, Rupe.

24 Luka Krmpotić Brnde, Veljun.

25 Podbilo, Francikovac.

26 Ivanka Atalić, Alan; Mara Tomljanović Isanova, Krivi Put; Luka Krmpotić Brnde, Veljun.

27 Svi ostali lokaliteti osim prethodno spomenutih izuzetaka.

28 U Francikovcu fonetska promjena - južna i mala južna. 
bila bijela kava i kruh, kava kruhom. U nedostatku kruha, česta je zamjena bila palenta. Također, čest jutarnji obrok bio je nadrobljen kruh u mlijeku ili bijeloj kavi, što mnogi Krivopućani i danas pripremaju.

Obroci su se razlikovali i prema prigodama. Tako su se određena jela priređivala prigodom godišnjih (primjerice Uskrsa, Božića) i životnih običaja (rođenja djeteta, svadbe, pogreba) te za utjecajnije goste (žandare, lugare i sl.).

Navedena podjela obroka na pet cjelina prakticirala se do šezdesetih godina 20. stoljeća. Procesom industrijalizacije obližnjih gradova (Senj, Rijeka i sl.) te prestankom ručnog obrađivanja poljoprivrednoga zemljišta, odlaska u košnju i na druge sezonske poslove, počinje slabjeti praksa ustaljenog načina prehrane s pet obroka dnevno.

U pripravljanju obroka značajne su bile osnovne namirnice poput soli, šećera, ulja i kave, a to se moralo nabaviti i debelo se naplatilo. ${ }^{29}$ Čest način njihova priskrbljivanja bio je odlazak na sajmove, ali i trgovine u Senj. Sol se najčešće nabavljala u Senju te se nosila u Slavoniju u zamjenu, rampu/trampu za druge proizvode (žito, kukuruz i kavu): Za sol ne znam da je ikada bila kriza, samo nije bilo šenice, brašna. Majka je išla, vozili smo sol u Slavoniju za šenicu, tako da smo imali. ${ }^{30}$ Sol se također nabavljala s Paga.

Marija Tomljanović Čna iz Krivoga Puta sjeća se kazivanja svoje majke koja je minjala robu za sol, te navodi: Majke naše išle na Pag. Ja se sićam dobro, nosila je jastučnice i one milje štikane, to mi je ostalo u glavi. A tako se nosilo i u Slavoniju, u ratu za hranu. E, puno se robe nosilo. Šenica i kokuruz je većinom, po to se išlo u Slavoniju.

Kata Prpić Copić iz Francikovca prisjeća se jednog od načina pribavljanja soli: Moj je otac pokojni iša u Senj po more. Pa dovezi i onda pokojna majka kuvaj i od toga napravi sol, a to nije bijela nego mrka sol.

Šećer, cukar, namirnica je koja se nabavljala u trgovinama: Onda su naše ženske od tih brda ozgora, sa konjima nosile su drva, pa su nosile i mlijeka, jaja i vako što bi, napravi sira i vrhnja, masla i tako to $i$ onda otidi tu u grad i donesi kave, cukra, petrolejuma. ${ }^{31}$ Ulje se koristilo u manjim količinama, a maslinovo se ulje nije koristilo ${ }^{32}$. U pripravi hrane imali smo mast od svinja svoji domaći. ${ }^{33}$ Mast se dobivala prilikom klanja odnosno svinjokolje, a čuvala se u posebnim zemljanim posudama, žarama.

\section{MLIJEKO I MLIJEČNI PROIZVODI}

$\mathrm{M}$ lijeko je predstavljalo jednu od važnijih namirnica Krivopućana, posebice tijekom 20. stoljeća kada se stanovništvo intenzivno bavilo uzgojem krava i u manjoj mjeri ovaca. Od mlijeka su se izrađivali mliječni proizvodi koji su predstavljali glavne prehrambene artikle područja Krivoga Puta: maslac, sir i kiselo mlijeko. ${ }^{34}$ Kazivači s područja Podbila pamte upotrebu i preradu isključivo kravljeg mlijeka i to za vlastite potrebe. Rjeđe je korišteno ovčje mlijeko, a neki ga kazivači pamte isključivo kao dopunu kravljemu: Tu i tamo znale babe starije malo ovčjeg mlijeka, pa sirile mlijeko od ovčjeg. ${ }^{35}$ Pere Tomljanović Rambula iz Tomića ističe kravice bile buše koje su davale i po pet litara mlijeka. Na području Krivoga Puta i Veljuna i u Tomićima u Podbilu ${ }^{36}$ potvrđena je mogućnost miješanja ovčjega i kravljega mlijeka, s obrazloženjem o gustoći ovčjega koje daje bolju i kvalitetniju kiselinu. Mužnja krava spadala je u ženski posao i obavljala

29 Marko Tomljanović Cote, Šimerićí.

30 Nada Prpić Terezina, Krivi Put.

31 Tome Špalj Cucin, Krivi Put.

32 Ivica Vukelić Pop, Rupa.

33 Marko Pavelić Mijatin, Žuljevići.

34 Ondašnja studentica etnologije Marija Friščić ispitivala je temu mliječnih proizvoda kod Marije Tomljanović Škorine iz Tomića (Podbilo) te je navela najznačajnije mlječne proizvode: sir, kiselinu i maslac. Usp. Friščić 2000: 236-237.

35 Milan Tomljanović Periša, Zamalić kod Alana. Nadalje, Katica Hotlovec iz Matić Gaja sjeća se kako se uz kravlje koristilo i ovčje mlijeko. Na području Podbila i Alana janjci su cicali, te mlijeka nije bilo za pravljenje mliječnih proizvoda.

36 S izuzetkom kazivanja Marije Prpić Vinine iz Veljuna; Friščić 2000: 236. U radu M. Friščić greškom se umjesto Tomića kao mjesto stanovanja spomenute kazivačice navodi susjedni zaselak Panjići. 
se dva ili tri puta dnevno, ovisno je li krava stelna ili se otelila. Mužnja ovaca ostala je nekim ženama u pamćenju kao težak fizički posao, ponajviše jer se ovce nisu dale musti tako lako kao krave. Svakodnevna mužnja zahtijevala je i trenutačno korištenje i pravljenje proizvoda. Stelna je krava nakon teljenja davala specifično mlijeko, grušalnu. Takvo se mlijeko nakon kuhanja ugruša, ono se svo zguža i to bude zgrudeno ${ }^{37}$, odnosno grušalna bi se pokvarila, prosjeklo jer nije bilo čisto mliko, to je bilo mlado ${ }^{38}$. Grušalna se upotrebljavala u pripravi kolača, najčešće štrudl (Žuljevići), štrudele (Francikovac), štrudle (ostali lokaliteti). ${ }^{39}$ Anka Vukelić Matićeva iz Rupe jedina donosi podatak da se grušalna koristila i u druge svrhe; mlijeko kad se krava otelila dali prascima, a onda drugo smo napravili štrudlu. Mlijeko se znalo i par dana grušati. ${ }^{40}$ Osim za pravljenje ukusne štrudle, grušalna se šećerila, a zatim jela žlicom što je posebno bilo ukusno djeci. ${ }^{41}$ Ovaj podatak potvrđuje i Zlata Tomljanović Pešina iz Krivoga Puta, te dodaje kako se grušalna mogla koristiti i za pravljenje palačinki. ${ }^{42}$ Miješanje mlijeka, jutarnjeg i večernjeg, nije se prakticiralo: ako se mliko miješa, jutarnje i večernje, onda bude kiseli sir. Treba biti jedno mliko, ako se ono pomiješa, već osjetiš promjenu. ${ }^{43}$ Mlijeko se miješalo kad su ga upotrebljavali za vlastite potrebe, što je bilo učestalije ${ }^{44}$. Nakon Drugoga svjetskog rata, kada su mlijeko dostavljali mljekarama, odvajali su jutarnje i večernje, u koje se moglo pomiješati i ono podnevno. Mljekare nisu dopuštale miješanje mlijeka, uglavnom zbog mjera higijenske predostrožnosti te mogućeg kvarenja mlijeka. Ipak, ukoliko je nedostajalo mlijeka za pravljenje nekih proizvoda, moglo se sastavit večernje i jutarnje. ${ }^{45}$

Na području Krivoga Puta zabilježena je upotreba naziva putar za maslac. Pravljenje ovog proizvoda identično je u svim lokalitetima: mliko se zakuva da se dobije skorup, koji predstavlja gornji, po dva prsta debeli i vrlo često žuti sloj mlijeka. Tome Špalj Cucin šaljivo dodaje kako je najbolji skorup onako debeo da može mačka po njemu proći.

Najbolje je mesti hladno mlijeko jer onda je to bez taloga. ${ }^{46}$ Putar se sabira dva, tri dana, recimo nisi im'o dovoljno za jedan pa si ostavio za sutradan il' dok se skupi (Ivica Vukelić Pop, Rupa). Skorup bi se stavljao u drveni $\operatorname{stap},{ }^{47}$ posudu visine jednog metra gdje bi se ručno melo pomoću mećaje, drvenog štapa koji na podnožju ima nekoliko rupica (sl. 1a, 1b). U Tomićima je zabilježen i naziv stapajica (Friščić 2000: 237). Udara jednu uru, po ure i onda izide putar što miriše ${ }^{48}$. Pravljenje putra ponajviše je zavisilo o količini mlijeka i tada dobivenog skorupa, a prema kazivanjima pravio se svaki dan, na drugi dan ${ }^{49}$ ili svakih nekoliko dana. U Žuljevićima kazuju melo se na stapić, dok u Alanu kažu melo se mliko. U ostalim lokalitetima upotrebljava se glagol mesti (mliko se mete). Marija Rončević Garina iz Alana se prisjeća: Moraš imati ritam u udaranju, to je umijeće. Bilo je tako da nije svako iz istog mlijeka izvadio isto putra, jer kao nisi istim tempom radio.

Domaćinstva koja nisu mogla potrošiti sav putar, nabrala bi pa bi trebalo topit..$^{50}$ Takvo pritopljeno maslo spremalo bi se u posude, žare u kojima je spremljeno moglo stajati i do godinu dana. Putar se kori-

37 Anka Šolić Tutanova, Podbilo.

38 Ista kazivačica.

39 Štrudla je kolač pripravljen od kore tijesta sa smjesom sira ili sezonskoga voća, primjerice višnje i sl.

40 Anka Šolić Tutanova, Šolići.

41 Milan Tomljanović Periša, Zamalić.

42 Palačinke se učestalije pripremaju tek zadnja dva desetljeća 20. stoljeća.

43 Marija Rončević Garina, Alan.

44 Prema kazivanju Anke Vukelić Matićeve, Rupa.

45 Milan Tomljanović Periša, Zamalić.

46 Katica Hotlovec, Matić Gaj.

47 Prema kazivanju Kate Prpić Čopić iz Francikovca stapove su pravili zanatlije znani u selima kao tišljari. Ostali kazivači spominju selo Kutarevo kao središnje mjesto izrađivanja drvenih predmeta.

48 Ivan Vukelić Mikula, Cupići.

49 Nada Prpić Terezina, Krivi Put.

50 Marija Rončević Garina, Alan. 
stio vrlo često kao namaz, ali se s njime i kuvalo, zamašćivalo i sve što je trebalo jer nije masti bilo. ${ }^{51}$ Jeo bi se i s palentom, a znali su ga i namazati na tijelo kako bi koža bila mekša. Otapanjem putra dobilo bi se maslo kojim se začinjavalo jelo. Maslo je moglo trajati duže od maslaca, a čuvalo se u kući u zemljanim čupovima od 5-6 litara (Ibid. 237).

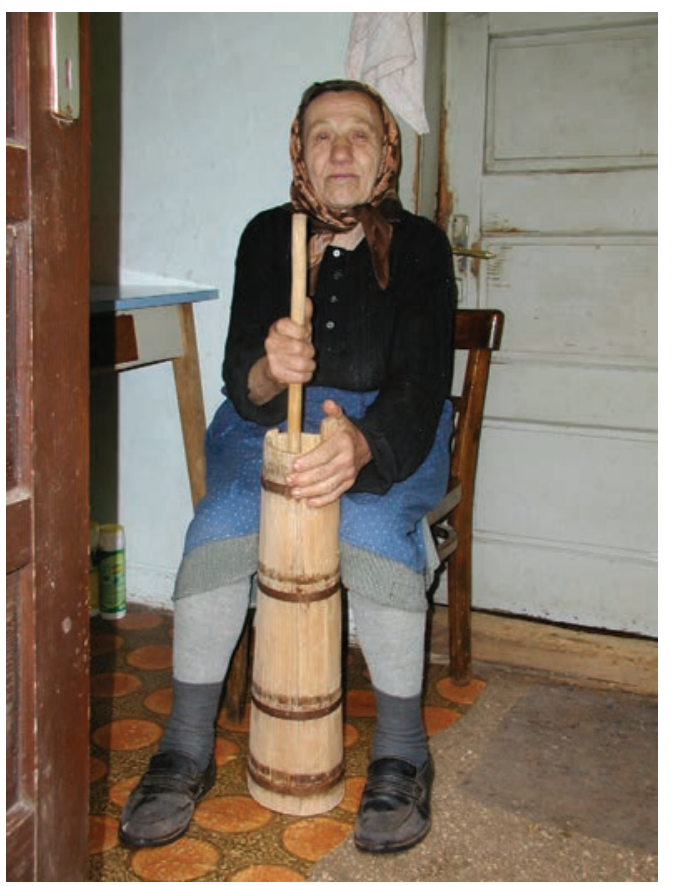

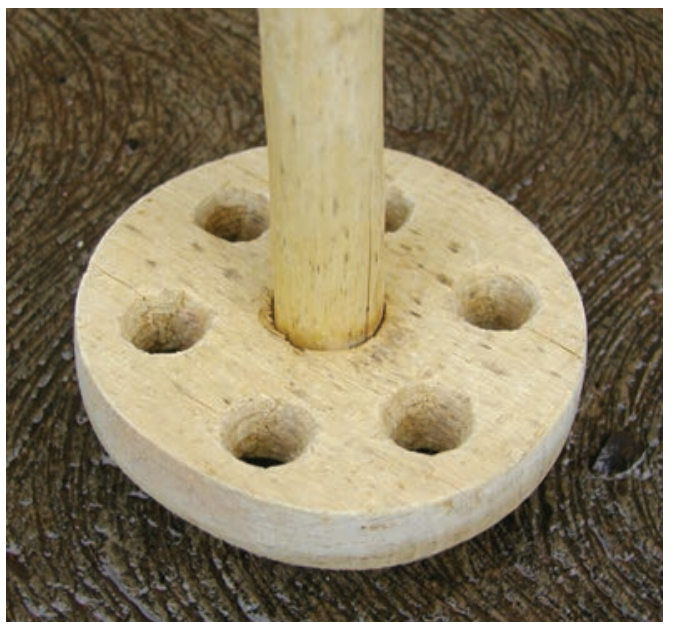

Slika 1b: Detalj stapa $i$ mećaje.

Slika 1a: Drveni stap $i$ mećaja, vlasnica Mara Krmpotic Brnde iz. Veljuna; snimila Jasmina Jurković, lipanj 2004.

Pravljenje sira u domaćoj radinosti poznato je i danas, a ističe se specifična vrsta škripavac koji posljednje desetljeće 20. stoljeća dobiva na sve većoj turističkoj pozornosti (sl. 2 a, b, c, d). ${ }^{52}$ U Tomićima mu se dodaje atribut bunjevački, a zovu ga još i friški sir (ibid. 236). Kazivač iz Žuljevića pamti važnost sira škripavca koja se izjednačava s oplodnjom, te kroz smijeh dodaje da je sira škripavca i one stvari sa Ritavca [Ritavac je lokalitet/op.a.]. Naziv škripavac kazivači objašnjavaju njegovim osobinama: frišak je (Rupa), kao škripi pod zubima (Matić Gaj, Alan, Cupići, Francikovac), čuje se pod zubima (Zamalić).

Osim škripavca, poznat je i suhi sir koji se dimio i sušio na dimu. Temelj za pravljenje sira predstavlja sirište koje se dobiva od telećeg ili janjećeg želuca, murice. ${ }^{53}$ Želudac je potrebno temeljito isprati, zatim usoliti te ostaviti nekoliko dana da odstoji (dva do tri dana). ${ }^{54}$ Murica se zatim rastegne na dva ili više štapića te stavi na sušenje. Izrezani komadići stavljaju se u posude s vodom koje se moraju dobro zatvoriti da bi se u njima napravilo sirište. Dobivenu tekućinu, sirište, ulijeva se u toplo, zagrijano mlijeko kako bi se sir usirio nakon približno dvajst minuta ${ }^{55}$. Nakon sat-dva u posudi, padeli sir dobio bi tvrđi oblik. Oblikovao se rukama ostavljajući pri tome tekućinu, surutku (Podbilo, Alan, Cupići, Rupa, Matić Gaj, Francikovac, Krivi Put) ili sirutku (Tomići), koja se najčešće davala svinjama, prascima (Alan) ili kokošima (Krivi Put). Siru se obavezno dodavala sol prilikom oblikovanja u kolut, da okrugli bude (Francikovac). Veličina sira zavisi od količine mlijeka upotrebljenog za pravljenje.

51 Katica Hotlovec, Matić Gaj.

52 Sir škripavac navodi se kao karakteristika dinarske kulturne zone; usp. A. Muraj 1998:103. Precizniji prostorni razmještaj pojave škripavca ograničen je na područje Like (Andrić 2003:28-29).

53 Manje detaljnu pripravu škripavca navode i J. Grčević 2000:109 te M. Hećimović-Seselja 1985:55.

54 Izuzetak predstavlja kazivanje Kate Prpić Čopić iz Francikovca koja kazuje da se želudac ostavi jednu noć u salamuri, odnosno soli.

55 Ivanka Atalić, Alan. 
Marija Rončević Garina iz Alana savjetuje da se manji sir pravi od pet litara, a ako je veći more i sedam, osam litara. Jedna žlica sirišta ulije se na deset litara mlijeka kako bi se dobio kilogram sira. Sir škripavac jeo se svjež i mogao je valjati dan do dva, a ukoliko ga je bilo više, dimio se na dimu i tako dobivao suhi sir, žut $i$ k’o kost tvrd (Francikovac). ${ }^{56}$ Sušio se na zraku i na dimu u sušarama (Francikovac), sušionama (Rupa) ili bajtama (Matić Gaj, Krivi Put, Tomići) ${ }^{57}$ na posebnim drvenim letvicama, k’o gajba za ptice, ali male šipke da sir ima zraka (Alan) zvane sirnjače (Zamalić, Alan, Rupa, Matić Gaj, Krivi Put, Veljun), siraljke (Krivi Put). Tvrdoća sira ovisila je o vremenskom periodu sušenja. Potrebno je bilo osam dana na dimu da bi bio umjeren (Alan). Nada Prpić Terezina iz Krivoga Puta ukazuje kako se sir mogao sušiti i u kuhinji, što ona danas i čini: Ja bi' metnila ovdje gore na elemente $i$ isto bi se osušija u toplini $i$ isto požuti.

Period valjanosti i upotrebljivosti suhoga sira bio bi i nekoliko mjeseci, što je ovisilo o načinu sušenja i prehrambenim potrebama. Za dimljenje sira značajna je bila vrsta drveta koja se upotrebljavala za loženje vatre. To je bila bukovina jer tu imamo najviše drva bukova (Krivi Put), svako drvo ima svoj sok u sebi, a drvo bukovina bila najprikladnija (Veljun). Priprava sira bila je za vlastite potrebe, da se omasti brk (Žuljevići), a većinom se odma jelo (Podbilo). Kao i danas, sirevi su se jeli svježi kao samostalno jelo uz kruh, iz ruke (Alan) ili su se kao suhi i tvrdi ribali na tijesto, što je predstavljalo ukusan dodatak obroku. Ivanka Atalić iz Alana navodi kako se suhi sir pripremao i s makaronima. Tijesto, sir i maslac koji se rastopio delao se za marendu, večeru, a nekad mog'o i za ručak. Osim proizvodnje za vlastite potrebe, škripavac se mogao i prodavati. ${ }^{58}$
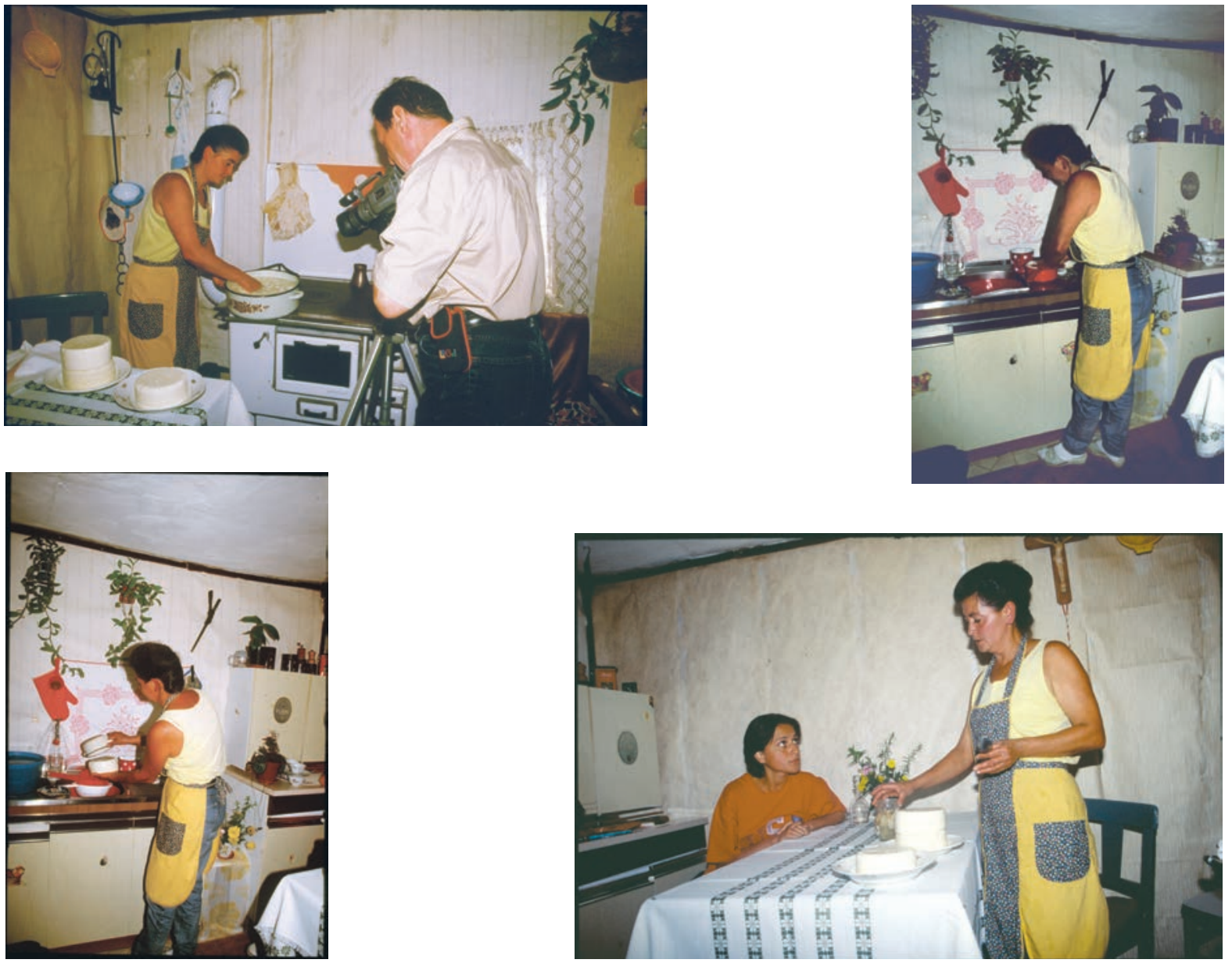

Slika 2a, b, c, d: Faz̧e ižrade sira škripavca, ižradila Marija Tomljanović iz Tomić; snimio Augustin Perić, kolovoz 1999.

56 Podjela na škripavac i suvi sir spominje se i u Ivčević-Kosi u Lici (Hećimović-Seselja 1985:56).

57 Bajte su zasebne gospodarske prostorije s otvorenim ognjištem, a često u upotrebi ljetnih kuhinja; (Friščić 2000: 236).

58 Marija Tomljanović iz Tomića i danas (2009.) proizvodi sir za prodaju. 
Kiselo mlijeko ili kiselina, naziv koji se upotrebljava u svim mjestima s izuzetkom u Zamaliću, gdje se koristio naziv kiselo, treći je značajni mliječni proizvod. U procesu metenja iz stapa, osim putra dobivala se tekućina metenica koja je služila kao temelj za pravljenje kiseline. Kiselina se pripravljala na sljedeći način: metenicu zagrijete, ne zavrit, mlako da bude, da prst ne zagori, pa dvi žlice kvasa i zamotaj u krpe i pokupi dobro, da nema zraka i to bi stalo preko noći $i$ sutra se to jelo. ${ }^{59}$ Tako napravljeno kiselo mlijeko bilo je čvrsto i stegnuto da si moga nožem rezat (Matić Gaj, Krivi Put). Gustoća kiseline bila je dobra kad bi kiselo na stol istresli ne bi se razliva. ${ }^{60} \mathrm{U}$ Tomićima spominju da se rijetko pripremala i ovčja kiselina, koja je bila gušća i masnija od kravlje. (ibid. 236) Navodi se i drugačija mogućnost kiseljenja: u mliko koje se treba ukiseliti stavi se malo kiseline od jučer, izmiješa se i pokrije, ostavi se do sutra i evo nove kiseline ${ }^{61}$. Kiselina se najčešće jela s palentom, što je potvrđeno u svim lokalitetima. Mogla se poslužiti također kao samostalno jelo uz domaći kruh ili, po potrebi, uz dimljene suhomesnate svinjske proizvode.

\section{MESO I MESNI PROIZVODI}

U potreba mesa uvelike je ovisila o godišnjim razdobljima, o ljetu i zimi. Tako su ljeti Krivopućani konzumirali mladu janjetinu koja se mogla upotpuniti svinjskim suhomesnatim proizvodima. Zimi se obavljala svinjokolja odnosno klanje svinja, pa se pretežito jela svinjetina i njezini proizvodi. Rad u polju, košnja i drugi ljetni poslovi iziskivali su bogatiju prehranu mesom. Zimi svinjetina predstavlja u svim mjestima najraširenije i najkvalitetnije meso. Mlade svinje, mlado, kupovali su se u proljeće i goji ga priko lita do listopada, studenog kako bi bili dovoljne težine za klanje kad su se pravili suhomesnati proizvodi i kad se osiguravalo dovoljno hrane za zimnicu. Naglasiti treba da se meso nije jelo svaki dan, nije bilo otkuda, puno dice i familije. ${ }^{62}$ Brojnost obitelji te neimaština i ekonomska oskudica uvjetovali su prehrambene navike pa se meso jelo dva puta nedjeljno, četvrtkom i nedjeljom. Pridržavanje ovog pravila potvrdili su svi kazivači. I danas, u nekim obiteljima nalazimo taj običaj da četvrtkom ima mesa. ${ }^{63}$ Većina se pak Krivopućana ne pridržava čvrsto ovoga pravila zbog relativne dostupnosti mesnih proizvoda i stabilnije ekonomske situacije. Obzirom na većinsku populaciju katoličkog stanovništva, uvriježena su crkvena pravila koja petkom nalažu nemrs, te su uz spomenute čimbenike odredila oskudniju upotrebu mesa. Osim janjetine i svinjetine, jela se i piletina, ali pretežito u juhi i u posebnim prigodama, najčešće nakon poroda (Žuljevići, Alan, Tomići, Šimerići, Rupa) ili u bolesti (Žuljevići). Zabilježeno tumačenje iz Rupe: kokica koja je bila starija znala se zaklat, žena kad se porodi dobivala je te juhe, koje se nadopunjuje kazivanjem iz Šimerića nije se kokoš uvijek klala, ne, ne to je morala gozba biti, pokazuje kako se velika pažnja pridavala spremanju jela od domaće peradi te se prema određenim prilikama poštovalo nepisano pravilo kako i zašto jelo treba biti spravljeno. ${ }^{64}$

U mesne proizvode spada i riba koja je prema kazivanjima imala sporedno značenje u prehrani. Riba se pribavljala u Senju, a vjerovalo se samo u jednu ribu, to je ona mala srdela. ${ }^{65}$ Upotreba riba srdelica u prehrani potvrđuju i kazivači u Veljunu i Krivome Putu. ${ }^{66}$ Ipak, strah od gušenja ribljim kostima kao i nestručnost pripremanja ribe, glavni su razlozi zbog kojih se riba izbjegavala u prehrani. U Alanu, Zamaliću i Francikovcu, usprkos tvrdnjama o slaboj prehrani ribom, poznavali su način konzerviranja ribe. Marija Rončević Garina iz Alana kazuje: Imali smo prije familije u Senju, pa bi napravili marinadu od fine ribe, pa

9 Marija Rončević Garina, Alan.

60 Marija Tomljanović Čonina, Podbilo.

61 Ista kazivačica.

62 Ista kazivačica.

63 Anka Šolić Tutanova, Šolići.

64 Ivica Vukelić Pop, Rupa i Marko Tomljanović Cote iz Šimerića.

65 Marko Tomljanović Cote, Šimerići.

66 Mira Tomljanović Ropeta, Krivi Put, Ivan Krmpotić Bokula, Veljun. 
bi ta riba mogla stajat. Ona se prži u ulju, izreže se puno kapule, lovorike i papra, ostike (ocat) i ta riba se složi u jednu padelu $i$ kad se to ohladi, zalije se to $i$ sad je konzervirano. U Alanu i Zamaliću potvrđuju uz srdele, konzumiranje i plave ribe lokarde.

Meso, pretežito janjetina i svinjetina, konzerviralo se na nekoliko načina. U ljetnim se mjesecima svježe meso, isključivo janjetina, stavljalo u kalače i spuštalo u šterne gdje bi bilo rashlađeno vodom, ali i da se sačuva od muve. ${ }^{67}$

S izuzetkom lokaliteta Rupa, gdje kazivači nisu potvrdili ovakav način konzerviranja mesa, ostali ukazuju kako se ono moglo očuvati do najviše osam dana. Ivanka Atalić iz Alana dodaje: Zaklali janje pa koristili kroz cijeli tjedan pomalo. Svježe meso koristilo se za vrijeme košnje, odnosno većih radova u polju. Zbog nemogućnosti adekvatnog konzerviranja životinju je zaklala jedna obitelj pa ju je podijelila s drugom, nakon toga druga je obitelj zaklala životinju te ju je opet dijelila.

Sušenje predstavlja drugi način očuvanja mesa, kojemu prethodi klanje, postupak u kojemu su se od svježega svinjskog mesa pravili suhomesnati proizvodi. Klanje se obavljalo u studenom, kad zahladi, najčešće oko blagdana Svih svetih (1. studenog), a moglo se obavljati sve do 29. studenog, što je predstavljalo zadnji datum klanja. Sam postupak obavljali su muškarci, dok su žene obrađivale i radile što spada. ${ }^{68}$

Zlata Tomljanović Peśina iz Krivoga Puta upućuje kako je bilo i iznimaka u podjeli poslova: bilo ih je koje su bile odvažne, uglavnom žene sve radile jer su muževi odlazili van, pa je na ženama bio sav teret. Mara Tomljanović Isanova iz Krivoga Puta sjeća se: nije tu žena pošteđena, tu je žena kao muškarac. Moralo se sve radit, nije se biralo ništa. Među ostalim kazivanjima preteže uvjerenje kako su muškarci radili klanja. Ipak, nisu svi muškarci znali klati, bio je meštar koji kolje (Rupa). ${ }^{69}$

Ivan Vukelić Mikula iz Cupića naglašava da kad se klalo, mi smo palili, nismo šurili, a Ivica Vukelić Pop iz Rupe nadopunjuje: Mi nismo imali tu vodu pa da smo šurili. ${ }^{70}$ Napravi se palilo, a to se napravio od drveta. Nabere se granja suvog $i$ kad se svinja zakolje, onda se metne na to, pa opali. ${ }^{71}$ Postupkom bi se paljenja skinule dlake sa svinje, a nakon toga bi žene ribale sa četkom, malo ju uredile. ${ }^{72} \mathrm{U}$ tom su poslu žene koristile krpe i četke (Krivi Put). Nakon paljenja i pranja svinja se rasporila, nožem se rezala i vadila drob van. Zatim se odvajaju debela od tankih crijeva, plećke, šunke, meso za nadijevanje crijeva, salo za topljenje, meso za soljenje i sušenje. Jetra ili žigerica bi se odvojila i odmah pripremala za sve prisutne za marendu (obrok između doručka i ručka). Salo, koje se pripremalo za topljenje, pregledalo bi se i izdvojilo za čvarke, cvirce (Rupa), čmarke (Matić Gaj, Francikovac). Uvriježen naziv je topiti čvarke, ali su oni brzo odlazili, kako navodi Ivica Vukelić Pop iz Rupe, odnosno brzo bi se pojeli. Nakon rezanja slanine na kockice, slijedi postupak topljenja nakon kojega će ostati čvarci. Za topljenje su se koristile drvene, a kasnije s vremenom i limene cidaljke, a kad bi se čvarci zasolili duže bi trajali.

Čišćenje, a zatim i nadijevanje crijeva, bio je isključivo ženski posao koji su obavljale starije žene dok su mlađe promatranjem učile, jer kad se uda ona je morala sve znat, delat, radit. ${ }^{73}$

Marija Rončević Garina iz Alana prisjeća se kako u stotinu voda treba isprati crijeva, a Mara Tomljanović Isanova iz Krivoga Puta nadopunjuje: Crijeva kad su se ošlajfala onda u pajc. Pajc se sastoji od soli, kapule, češnjaka, papra u zrnu, lovorike pa tako prinoći u tome. Sutradan se vadi iz otoga, još se ispere u par

67 Meso nije bilo u vodi, nego iznad nje, u posudi kalači.

68 Luka Krmpotić Brnde, Veljun.

69 Luka Krmpotić Brnde iz Veljuna pamti majstora koji je raspoređivao meso i kojega su pozivali na klanja.

70 Postupak klanja Krivopućani uspoređuju s, čini se dobro im znanim, postupkom u Slavoniji gdje se dlake skidaju šurenjem svinja. Opisujući postupak klanja svinja u Slavoniji, M. Kadić donosi: Današnji način klanja svinja je prilično poznat. Nema više palenja, nego se nakon klanja svinjče šuri u koritu nakon polijevanja i okretanja u vreloj vodi. (Kadić 1976:49)

71 Katica Hotlovec, Matić Gaj.

72 Anka Vukelić Matićeva, Rupa.

73 Katica Hotlovec, Matić Gaj. 
voda $i$ onda se idu radit krvavice. A to sve da nemaju mirisa. Svi kazivači navode kao specifičnost ovog kraja pravljenje divenica - krvavica (svi lokaliteti) ili krvavih kobasica (Matić Gaj, Zamalić). To su kobasice koje su se pravile od žutog, kukuruznog brašna, masnoće odnosno sala strbuva svinjskog, mirodija: papra, češnjaka, soli, kima i javorikel lovorike (lovorovog lista) te svinjske krvi. Svi se navedeni sastojci pomiješaju te se dobivenom smjesom nadjenu debela crijeva, koja se zatim kuhaju odnosno obaraju (Zamalić, Krivi Put).

Koristan je savjet iz iskustva, da se prilikom kuhanja krvave kobasice štapićem probuše na nekoliko mjesta kako se ne bi raspuknule. Skuhane kobasice potom su se dimile, čime bi proces njihova pravljenja bio završen..$^{74}$ Ivica Vukelić Pop navodi: Žene bi šile žaklje, negdje dvadeset i pet centimetara sa osam ili devet i ostatak smjese u tu žaklju. Ivan Krmpotić upozorava kako bi se žaklje trebale prve kuhati, ali i prve pojesti, jer zbog njihova materijala nije bilo poželjno da dulje stoje. Zlata Tomljanović Pešina iz Krivoga Puta navodi: Ako je bila kvalitetna kobasica to je bila jako kvalitetna domaćica.

Nadijevanje kobasica vršilo se pomoću limene mašine. Imali smo prije šprice za nadivat kobasice. Meni je majstor napravio, ko flaśa jedna, dole je bilo šuplje pa je napravio tratur, a ovdje smo imali drveni ko valjak što smo gurali unutra. Pa bi navukli na taj tratur crijeva i onda upirali i nadivaj tako. E, a poslije smo se spametili, imala sam flašmašinu za meso pa sam napravila traturić na nju i lipo na nju ta tanka crijeva i lakše je, nisi mora upirati. Ja sam dvadeset i treće godiste a tako se radilo i kad sam bila mala, više na ruku, a poslije se isto opametili kako bi lakše. Još prije naše babe su žice svini i napravi pa u crijevo i nadivali, sjeća se Zlata Tomljanović Pešina iz Krivoga Puta.

Osim krvavica, pravile su se i mesne kobasice od sječenog mesa (ne strojno mljevenoga), paprike, soli i češnjaka. Marija Rončević Garina iz Alana napominje kako nisu svi imali mašinu, pa se sjeklo ručno to meso, jer mašina puno zgnjavi. Ona ističe da su se četrdesetih godina 20. stoljeća pojavile prve mašine, ali nakon Drugoga svjetskog rata, tijekom pedesetih godina 20. stoljeća, nabavljale su se lakše pa ih je bilo i više u upotrebi. Katica Hotlovec iz Matić Gaja ocjenjuje obično se sjeklo, jer puno je ukusnije nego ono što se melje. Mesne kobasice, kao i krvavice kuhale su se, ali kraće od krvavica, nakon čega su se sušile nekoliko dana. Svi su kazivači potvrdili da se kobasice kuhaju, suše i dime. Podatak da su se prije mećale suve kobasice u žito, kako bi se sačuvale, dobiven je samo od Mare Tomljanović Isanove iz Krivoga Puta. ${ }^{75}$ Poznate su i kobasice - mure i danke. ${ }^{76}$ Radi se o mesnim proizvodima pripravljanim od smjesa za krvave kobasice u svinjskim želucima - murama. Ovaj specijalitet ostavljao se za Božić kada se nanovo kuhao.

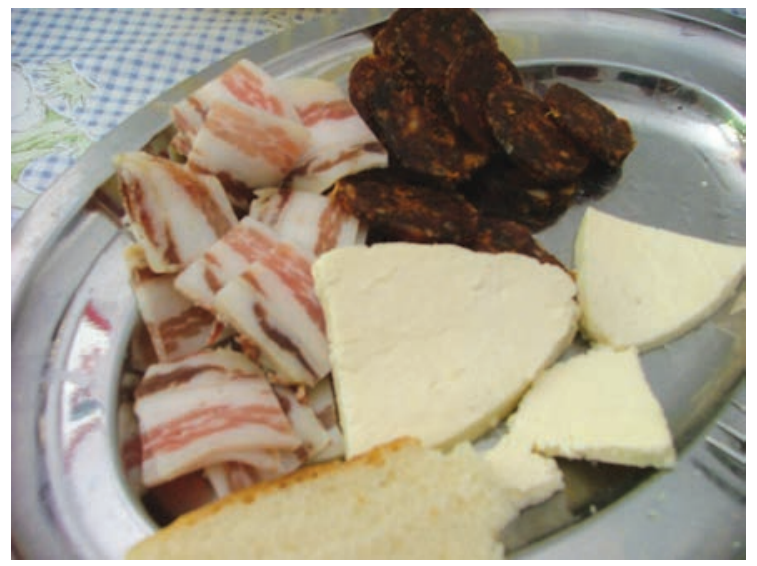

Slika 3: Suhomesnati proizvodi (slanina i mesne kobasice), sir škripavac i kruh, u Rusovoj Dragi, kod Miroslave i Ante Prpić Rus; snimila Tihana Rubić, lipanj 2004.

74 Ivica Vukelić Pop iz Rupe te Ivan Krmpotić Bokula iz Veljuna jedini donose podatak o platnenim žakljama koje su, u nedostatku debelih crijeva, mogle poslužiti kao nadomjestak.

75 Ostali kazivači nisu upitani za ovu pojavu, ali je nisu ni spomenuli.

76 Izuzetak od podjele na krvave i mesne kobasice predstavlja kazivanje Luke Krmpotića Brnde iz Veljuna koji navodi nazive mura i danka označujući krvave i mesne kobasice. Mara Tomljanović Isanova pod nazivom mura navodi jelo za Božić pripravljeno kao krvava kobasica ali u telećem želucu, ne u crijevu. 
Nakon što se meso raspravilo, ono bi se solilo i stavljalo u drvenu veliku kacu (Rupa, Tomići), lonac (Alan), kantu (Francikovac) ili u drveni badanj (Matić Gaj, Cupići). Usoljeno bi meso u vodi davalo tekućinu, što se naziva salamura ili pac. ${ }^{77}$ Duljina držanja mesa u salamuri ovisila je o vrsti mesa. Tako se najdulje (tri tjedna ili 21 dan) drže šunke, pršuti koji trebaju poprimiti više soli, dok se ostalo meso (slanina, krmenadli) držalo dva tjedna. Držanje u pacu ovisilo je i o količini soli i o vremenu. Tako Zlata Tomljanović Pešina iz Krivoga Puta kaže: ako je hladnije onda se sporo otapa, a ako je mekše onda se brže otapa sol. Zatim sve meso ide na sušenje i dimljenje.

Kata Prpić Čopić iz Francikovca savjetuje za postupak dimljenja: treba pomalo svaki dan, ne naglo, malo tako da ono požuti, a onda se digne na tavan i tako stoji. Vatra se ložila svaki dan, ali se pazilo da plamen ne bude jak te da se meso dimi samo na dimu. Luka Krmpotić Brnde iz Veljuna navodi kako je potrebno imati suva drva, da vatra gori, ne da jako dimi. Ukoliko bi puhalo jugo, onda bi potegnulo dim, a kad bi zapuhala bura ne bi bilo dima, pa je tada i pogodnije vrijeme za sušenje. Vrsta drveta je, kao i kod dimljenja sira, bila od posebne važnosti. Bukovina je bila najcjenjenije drvo, a jelovina nije jer povlači miris, pa nije dobra. Jedino su u Rupi kazivači naveli postupak cijeđenja pršuta kako bi izašla voda iz salamure, jer šunka dođe onako bublasta, a ovako bude ravna. ${ }^{78} \mathrm{U}$ ostalim mjestima Podbila smatraju da prešanjem izade sva slast. Na području Krivoga Puta i Veljuna poznat je postupak prešanja a duljina zavisi od jednog dana, da se ocijedi, ${ }^{79}$ pet dana ${ }^{80}$ ili najmanje tjedan dana. ${ }^{81}$

Gotovo bi svi dijelovi svinje bili iskorišteni, pa se tako od kožica, ušiju i nožica uz dodatak slanine pravila ćeladija. Ivica Vukelić Pop iz Rupe naglašava: Mi smo ovdje bili specijalisti za rastrančivanje, ovdje nije ostajalo ništa, jedino onaj papak. Nakon što se spomenuti dijelovi svinje dobro operu i očiste, onda se kuhaju. Usporedo se kuha i juha u koju se dodaju skuhani dijelovi. Nakon hlađenja, juhu treba preliti u manje posude iz kojih će se ćeladija jesti a ona će se stisnuti. To jelo ima svojstvo hladetine i koristi se u prehrani oko Božića i Nove godine. ${ }^{82}$ Bezbuš je vrsta jela koja se spravlja tako da se debelo crijevo napuni smjesom napravljenom od skuhanih svinjskih nožica, kožica, glave, krvi i ćeladije, a zatim se skuha. ${ }^{83}$

Sljedeći način konzerviranja mesa, koji poznaju na području Krivoga Puta, prelijevanje je mašću (Alan, Rupa). Pečeno meso prelijeva se mašću da bi takvo moglo stajati nekoliko dana. Posljednji je način konzerviranja mesa, zabilježen na ovom području, pomoću leda. ${ }^{84} \mathrm{Na}$ području Krivoga Puta i Mrzloga Dola napominju kako je pravljenje leda bila osobitost Veljuna. ${ }^{85}$ Kazivači bi s toga područja gotovi led rezali u oblik kvadra te ga stavljali u vreće i gonili magarcima u Senj. Led bi prodavali slastičarnicama i mesnicama, a važno je da si prije sunca u Senju jer se led moga' rastopit.

Postupak izrade leda obavljao bi se u zimskom periodu: Iskopala bi se rupa i onda se toga nabi da bude ilovača, onda sniga natrpa. Napravi se drveni bat pa se taj snig izbatira, pa pokri sa šušnjom listom i onda grane, tako da bude led. ${ }^{86}$ Rupa ili jama se zvala snižnjača. Luka Krmpotić Brnde iz Veljuna tako je nastavio obiteljski posao koji je preuzeo od oca koji se također bavio pravljenjem leda. On navodi još dvije obitelji

\footnotetext{
77 Naziv pac, uz naziv salamura, spomenuli su Ivica Vukelić Pop iz Rupe i Pere Tomljanović Rambula iz Tomića. Ostali kazivači istaknuli su naziv salamura kao jedini.

78 Anka Vukelić Matićeva, Rupa.

79 Mira Tomljanović Ropeta, Krivi Put.

80 Ivan Krmpotić Bokula, Veljun.

81 Luka Krmpotić Brnde, Veljun.

82 Vidjeti dalje u tekstu pod naslovom: Jela i njihovo pripravljanje.

83 Nisu svi kazivači ispitani o bezbušu. Podatak je zabilježen u Krivome Putu.

84 Vidi o prodaji leda više u prilogu Tihane Rubić o tradicijskoj trgovini u prvom svesku Monografije, str. 340-341.

85 U lokalitetima Podbila, izuzev Cupića, nije zabilježeno nijedno kazivanje o sjećanju pravljenja leda, a Ivan Vukelić Mikula iz Cupića poznaje tehniku pravljenja leda, ali ne iz njegova mjesta.

86 Ivan Krmpotić Bokula, Veljun.
} 
koje su na takav način mogle zaraditi za namirnice i druge potrepštine. Posao je napustio nakon Drugoga svjetskog rata jer se to rasulo, krenuli su frižideri.

\section{6. ŽITARICE I KRUH}

$\mathrm{L}$ okalne i regionalne mogućnosti poljoprivrede predstavljaju značajan uzročno-posljedični faktor u skali prehrane na ovom području. Ivanka Atalić iz Alana objašnjava: Zemlja se obradivala, žito se sijalo i ječam jer prije se nije imalo nešto drugo. Sadilo se zelje, mrkva, a sam čovjek obradivao je na motiku. Bilo je i plugova, ovi zaprežni, ali nije svaka kuća imala, pa su posudivali.

Najznačajnije žitarice su ječam i pšenica, dok su zob i proso manje zastupljeni. ${ }^{87}$ Kukuruz se nije sadio, ali je u prehrani bio zastupljen. Nabavljao se u Senju, Karlovcu ili u Slavoniji. ${ }^{88}$ Marija Rončević Garina iz Alana spominje vrstu žitarice jeldu od koje se također pravio kruh. ${ }^{89}$ Ona navodi: to je jedna vrsta žitarice što izgleda ko p̌senica samo je sitnije, a daje jako slatki kruh. Ako se samo od nje kruh je onda mljecav. Zob se upotrebljavala za prehranu životinja, ali Marko Tomljanović Cote iz Šimerića ističe zobenu kašu kao jelo koje se pravilo kad nije bilo drugih žitarica, odnosno u Drugom svjetskom ratu i poratnom razdoblju. ${ }^{90}$ Milan Tomljanović Periša iz Zamalića ukazuje i na ječam kao namirnicu koja se koristila za pravljenje kruha u ratnom periodu. Dobiveno zrnje nosilo bi se mljeti na vodenice u Brlog, ${ }^{91}$ Prokike, ${ }^{92}$ Brinje te Žrnovicu na moru iz Alana. Najčešći oblik plaćanja za mljevenje zrnja i dobivanje brašna bio je ujam. Omjer bi bio dogovoren, a iznosio je: na sto kilograma brašna uzimalo bi se od tri do pet litara (Veljun) ili 10\% (Krivi Put). Samljeveno zrnje bi se dovozilo u platnenim vrećama, a zatim bi se spremalo u drvene kasune na tavanima te si po malo trošija.

Kruh se pekao pod pekom, što je predstavljalo stariji način, ili $u$ roli odnosno u štednjaku što je zastupljenije od šezdesetih godina 20. stoljeća. Zlata Tomljanović Pešina iz Krivoga Puta, kako sama ističe, nije pekla kruh pod pekom, nego u roli, i to od 1947. godine kada se udala. O pravljenju kruha pod pekom i njezinu razlogu ne korištenja peke kaže: da vam budem iskrena, nije više bio ni običaj. Ivanka Atalić iz Alana pojašnjava: 'Ko nije imao ognjište, peko je u roli. Među kazivačima uvriježenije je mišljenje kako se ljeti kruh pekao pod pekom u bajtama, dok se zimi pekao u kućama, u rolama (svi lokaliteti) ili $u$ šparhetu

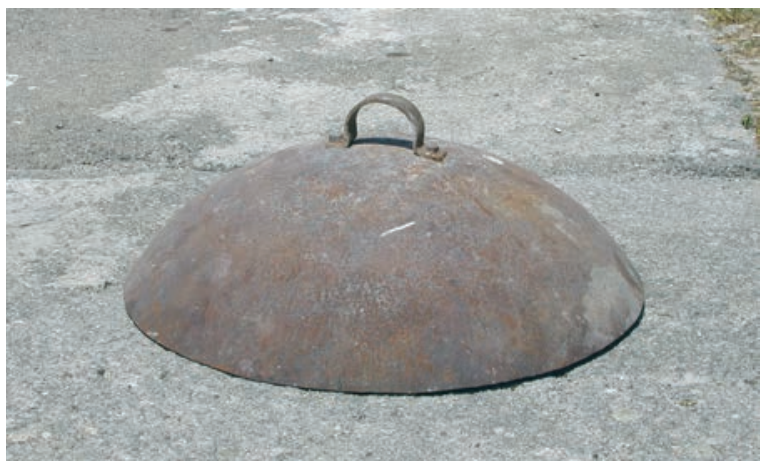

Slika 4: Peka, vlasnica Jula Tomljanović Marićeve iz. Alana; snimila Jasmina Jurkovic, lipanj 2003.

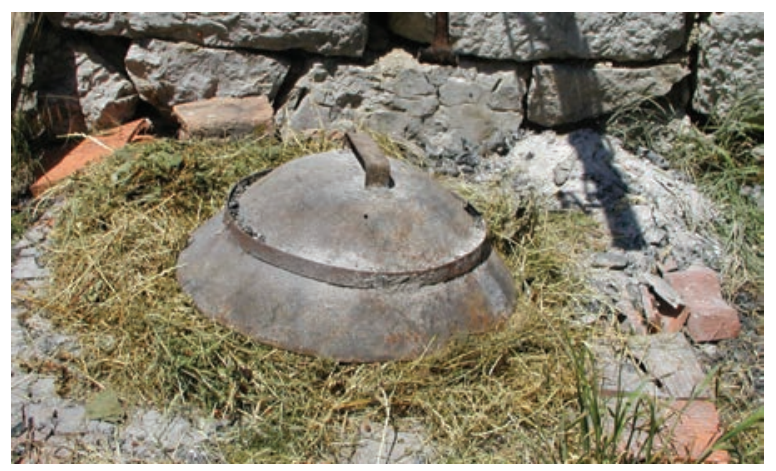

Slika 4a: Peka, vlasnike Milan Tomljanović Kanada iz. Žuljevića; snimila Jasmina Jurković lipanj 2003.

\footnotetext{
87 Više vidi u prilogu Marijete Rajković o zemljoradnji u prvom svesku Monografije.

88 Pojam „Slavonija“ je kod kazivača proširen na velik dio kontinentalne Hrvatske i obuhvaća romantičnu sliku o bogatstvu u materijalnom i duhovnom obliku. (Usp. prilog o odijevanju Aleksandre Vlatković u ovom svesku Monografije).

89 Izuzev lokaliteta Mrzli Dol i Alan, u ostalim lokalitetima nije spomenuta žitarica jelda.

90 To potvrđuje i Katica Hotlovec iz Matić Gaja.

91 Mira Tomljanović Ropeta, Krivi Put.

92 Luka i Mara Krmpotić Brnde, Veljun.
} 
(Rupa). ${ }^{93} \mathrm{Na}$ Krivome Putu zastupljena je peć zvana koza. Peke su bile okrugle, vrlo često od gusa, pa otuda i naziv gusane peke, ${ }^{94}$ željezne, limene ${ }^{95}$ ili plehnate. ${ }^{96}$ Marija Rončević Garina iz Alana sjeća se kako je bilo i starijih zemljenih peka, što su se pravile u Lici, ali i Bosanci su ih znali praviti, a oni se vozili po selu i prodavali (sl. 4, 4a).

Namještale su se pomoću željeznoga ožaka (žarač). Peke su imale rupice koje su omogućavale izlazak vruće pare. Prije postavljanja peke i kruha pod nju, ognjište bi se pomelo pomoću nekoliko skupljenih velikih pijetlovih pera (Krivi Put). U nedostatku istih, mogla su poslužiti i pera kokoši svezana u metlicu. Gazdarica bi osobitu pozornost trebala posvetiti vatri i njezinu loženju. Za pripremu kruha upotrebljavao se domaći kvas, brašno, sol i voda. Marija Tomljanović Čnina iz Podbila ističe mlakaste vode da se ne bi kvas oparija ili ako je jako ledena onda se teže diže, a vruća voda kvas izgori. Lipo mlakasta voda da se dobro kvas rastopi. Domaći kvas, potvrđuju svi kazivači, ostavljao se od prethodnog kruha. Kad se mijesio kruh, komadić tijesta stavljao se u padelicu s malo brašna, gdje bi se ukiselio, ukvaso do sutradan kad bi bio spreman za novi kruh.

Veličina kruha ovisila je o veličini peke, bio je ko kotač ${ }^{97}$. Brašno koje se upotrebljavalo bilo je šenčeno, šenično odnosno pšenično. ${ }^{98}$ Kruh se mijesio u drvenim naćvama, korito koje je bilo iskopano od bukovog drveta. ${ }^{99}$ Anka Šolić Tutanova iz Šolića prisjeća se kako se prije Drugoga svjetskog rata mijesio kruh u naćvama, ali dodaje da se mijesilo i u velikoj rajni (rajnika, zdjela).

Luka Krmpotić Brnde iz Veljuna naglašava da se kruh sastoji i od gazdarice, neke znadu bolje, neke loše i ne moš jest. Iako se kruh pekao svaki dan, nije ga bilo u izobilju, nije se kruh jeo kad se htio. ${ }^{100}$ Upravo zbog

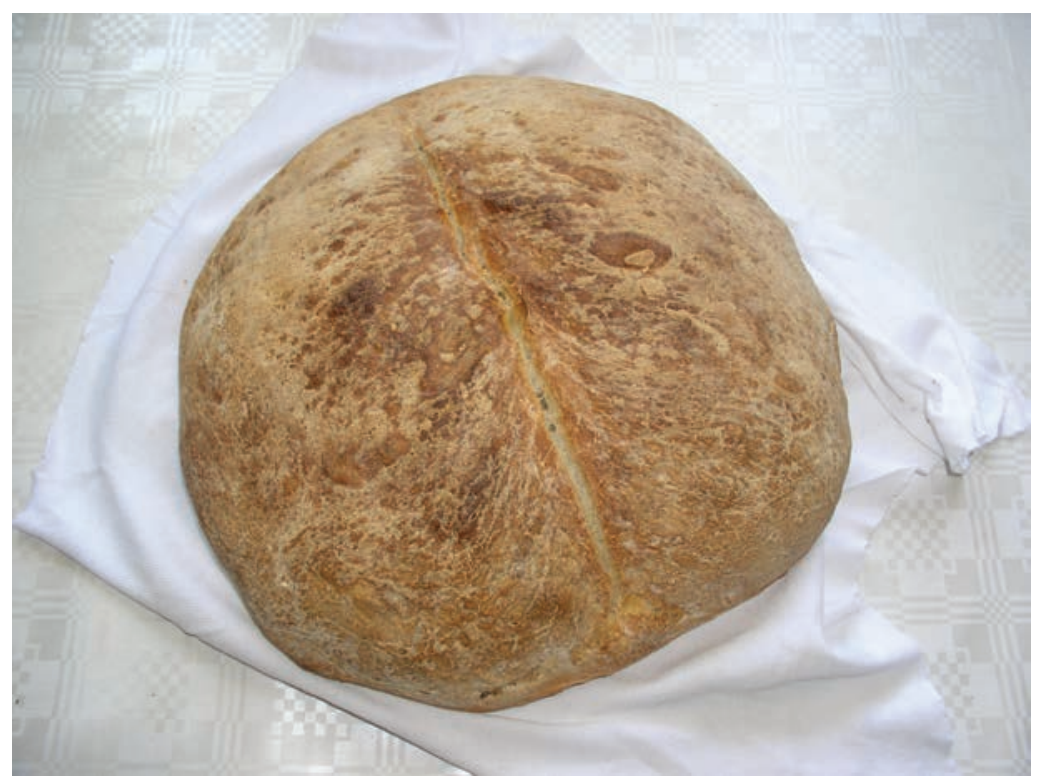

Slika 5: Kruh, ižradila Anka Šolić Tutanova, Šolicí; snimila Marijeta Rajković, lipanj 2006.

\footnotetext{
93 Šparhet je naziv za štednjak na drva.

94 Kazivači su različito definirali materijal gus, ali su ga uglavnom poistovjećivali sa željezom.

95 Pere Tomljanović Rambula, Tomići.

96 Mira Tomljanović Ropetina, Krivi Put.

97 Katica Hotlovec, Matić Gaj.

98 Kazivanja se podudaraju u tome da se često miješalo pšenično i ječmeno brašno, a sve zbog manjka pšenice.

99 Milan Tomljanović Periša, Zamalić; Naćve je naziv za dubeno korito od jednoga komada drveta postavljeno na klupu ili u stalke na četiri noge.

100 Marko Tomljanović Cote, Šimerići.
} 
nedostatka hrane, pazilo se na svaki komadić. Svi se kazivači sjećaju kako se kruh davao na šnite (Cupići), mama da komad kruha, a ostalo zaključa (Šolići). Osim šeničnog kruha (sl. 5), pravio se i bijeli kruh cvajer nazvan prema tipu brašna koje se upotrebljavalo za njegovu pripravu (Žuljevići, Alan). U Veljunu se još uvijek prisjećaju kako je pod pekom kruh najukusniji.

\section{POVRĆE I VOĆE}

$\mathrm{N}$ ezamjenjiva namirnica u prehrani stanovništva ovoga područja je krumpir. Među Krivopućanima uvriježeno je mišljenje o poznatom ogulinskom kupusu, krivoputskom krumpiru i dabačkom grahu. ${ }^{101}$ Posebno su zastupljene dvije vrste krumpira: crveni i žuti ili bijeli koji se često naziva koravac. ${ }^{102}$ Ostale poznate vrste su: čulin (Cupići), marko (Krivi Put, Mrzli Dol), rozi, dezerejac (Krivi Put) ili dezere (Mrzli Dol), jerla, monalisa (Krivi Put). Krumpir se koristio u prehrani kao dodatak ili samostalno jelo. Čuvao se u trapovima, posebnim podzemnim prostorijama u kojima se po potrebi moglo čuvati i drugo sezonsko povrće (mrkva, peršin i dr.). Mara Tomljanović Isanova iz Krivoga Puta tvrdi kako su žene međusobno mijenjale sjeme krumpira te otuda mnoge vrste i različiti nazivi za krumpir.

Tijekom cijele godine u prehrani se upotrebljavao i kiseli kupus, zelje. Sijanje kupusa obavljalo se u proljeće. Često se ostavljao priranak - glavica kupusa iz koje će izrasti sjeme koje se, nakon sazrijevanja, pokupi i čuva za sljedeću godinu. ${ }^{103}$ Priprema bi započinjala s jeseni, u listopadu, kada bi se glavice kupusa čistile, a neke ribale i stavljale u drvene badnje, kace, odnosno bačve koje bi se držale u podrumima, na hladnome (sl. 6). Kupus bi ostajao u badnjima dok se ne bi potrošio, a trajao bi do sljedećega kiseljenja. U Veljunu procjenjuju da ukoliko je veća obitelj, potrebna su i dva badnja od po dvisto litara za jednu godinu.

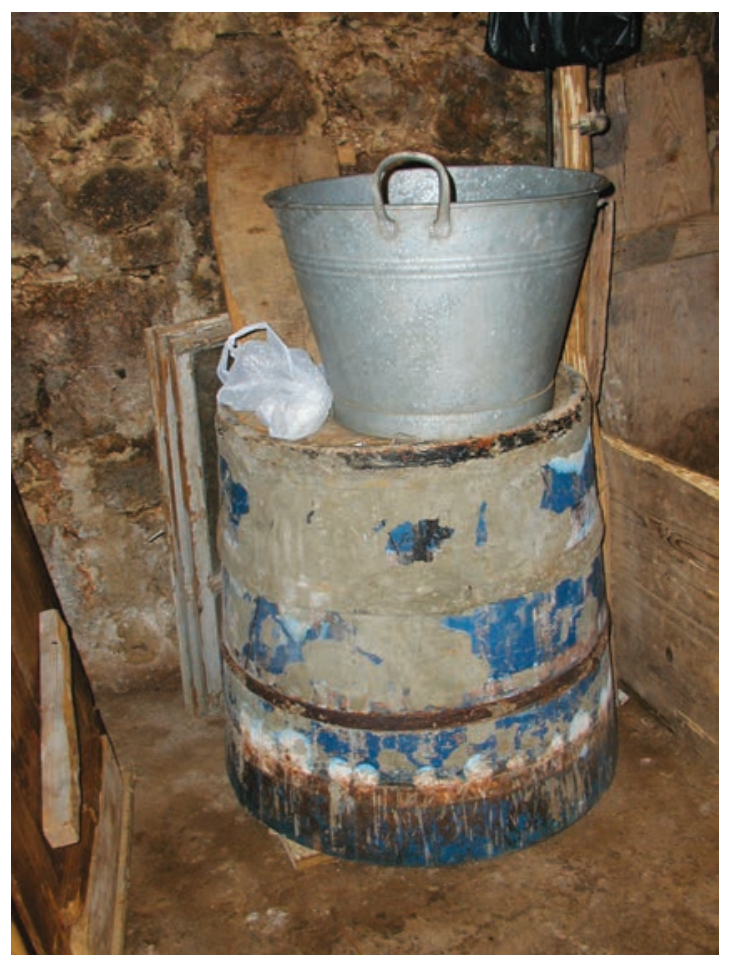

Slika 6: Drveni badanj za kiseljenje kupusa, vlasnik Luka Krmpotić Brnde iz. Veljuna; snimila Jasmina Jurković, lipanj 2004.

\footnotetext{
${ }_{101}$ Kao izreku navela ju je Zlata Tomljanović Pešina iz Krivoga Puta.

102 Jedino je Milan Tomljanović Periša iz Zamalića objasnio kako je koravac crveni krumpir, dok su svi ostali tvrdili da je to bijeli krumpir. U Francikovcu je Kata Prpić Čopićeva istaknula podjelu na crveni i bijeli krumpir, odnosno dezere i koravac.

103 Pere Tomljanović Rambula, Tomići.
} 
Posao kiseljenja kupusa nije bio strogo reguliran nepisanim pravilima prema spolovima, kao postupak svinjokolje u jesen. Kupus bi ribali muškarci iako to pravilo nije čvrsto određeno, pa su po potrebi to mogle obavljati i žene. Stavljanje kupusa u drvene badnje obavljalo bi se tako da se prvo odredila količina glavica koje se ne bi ribale, a od kojih će se praviti jelo sarma. Te bi se glavice posebno solile i to tako da se izdubi korijen glavice umjesto kojeg se stavlja sol. Nakon jednog vodoravnog reda glavica kupusa, stavljao bi se ribani kupus. Vrlo je važno ribani kupus pritiskati kako bi ispustio vodu koja bi se digla iznad njega. Taj bi posao često obavljala djeca, pritom se zabavljajući. Sol bi se stavljala nakon svakog reda glavica, a nakon kante ribanoga kupusa - šaka soli. ${ }^{104} \mathrm{Kad}$ se sav kupus stavi u drveni badanj, dodaju se voda, sol i zrnje nekuhanoga kukuruza radi boje i čvrstoće kupusa (Veljun). U Krivome Putu za čvrstoću kupusa stavljali bi koru 'rena (hrena) i papar u zrnu. ${ }^{105}$ Jedini podatak o stavljanju čavla za čvrstoću kupusa zabilježen je u Šolićima. Kako bi kupus bio pod stalnim pritiskom, na njega se stavljaju drvene daščice, peze (Šolići, Francikovac, Krivi Put, Veljun) ili duge (Rupa) i kamen (sl. 7). Kupus bi se ostavio od dva tjedna do mjesec dana i u tom bi razdoblju započeo proces kiseljenja. To je vidljivo po dizanju vode, koja se naziva rasol (Francikovac) i pjenjenju. Osim za kiseljenje, svježi se kupus mogao ostavljati i za zimski period kada bi se pravio za variva, ćušpajze. Za čuvanje je bilo potrebno okrenuti palicu, korijen prema gore kako bi se kupus sasušio, ali ne i uvenuo i potrunio.

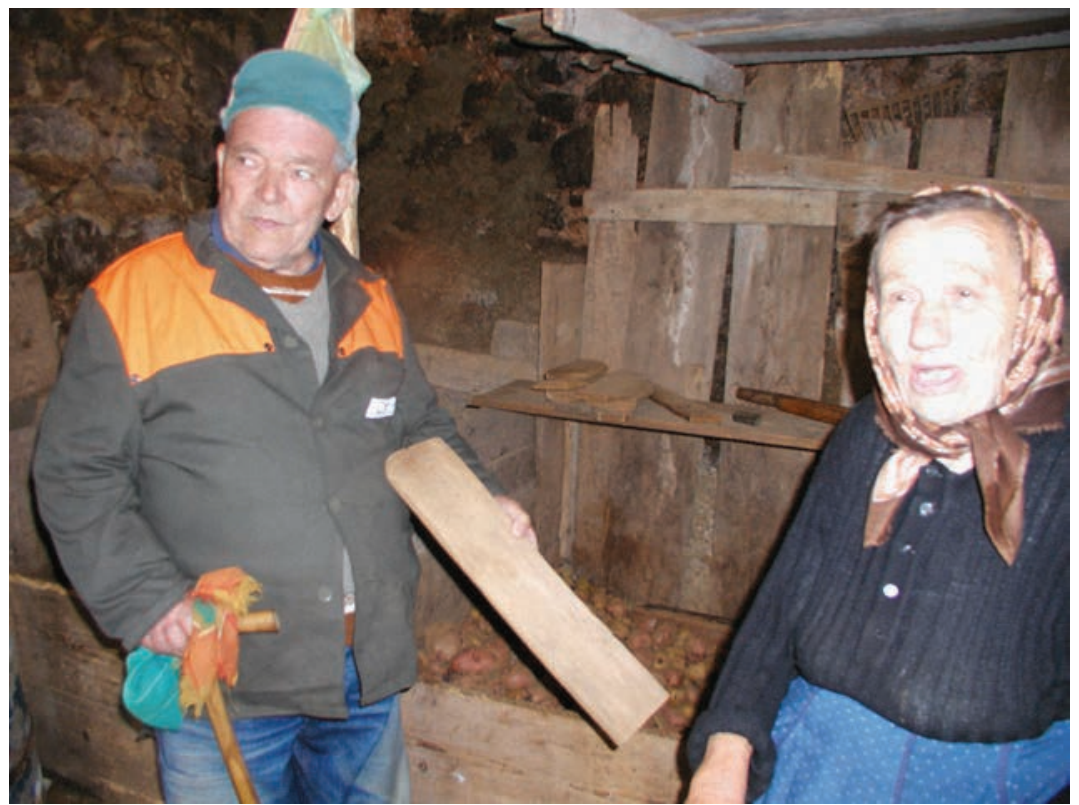

Slike 7: Drvene dašrice peze; vlasnici Mara i Luka Krmpotic Brndini s Veljuna; snimila Jasmina Jurković, lipanj 2004.

Osim zelja, u prehrani je bilo prisutno i drugo sezonsko povrće. Svi kazivači navode blitvu kao vitaminima bogatu namirnicu od koje se pravi ćušpajz, odnosno varivo. Čest naziv za pripravljanje ćušpajza je: na žlicu. Blitva se također, kao i kupus, mogla ribati i kiseliti (Matić Gaj) te tako sačuvati i za zimski period. Ukiseljena repa također se spremala u zimnicu. ${ }^{106} \mathrm{U}$ toplijim razdobljima, proljeću i ljetu, bralo se divlje bilje kao što su divlja kopriva od koje bi se pravio ćušpajz, zatim ušac, kopar, komorada i divlji radič. Uz samoniklo bilje, sadila se u vlastitom vrtu i mrkva, peršin, cikla, paprika, rajčica - paradajz i zelena salata. ${ }^{107}$ Povrće se za zimnicu rijetko kiselilo. Posljednjih desetak godina ta je praksa učestalija,

\footnotetext{
104 Savjetuje Kata Prpić Čopić, Francikovac.

105 Nada Prpić Terezina, Mrzli Dol.

106 Podatak ne navode svi kazivači, nego samo oni u Alanu i Krivome Putu.

107 Detaljnije o povrtlarstvu vidi u poglavlju o zemljoradnji Marijete Rajković, u prvom svesku Monografije, str. 221247.
} 
premda se tim poslom bave samo pojedine žene. Primjerice, Anka Šojat Colaševa, rođena u Gospiću, udana u Francikovac prije četrdeset godina, pravi zimnicu od krastavaca, cikle, paprike (punjene, rezane), feferona, turšiju (miješano povrće). Sve povrće sama sadi, osim paprike koja u ovome kraju ne uspijeva. Ona također za zimnicu radi ajvar i domaću vegetu (sl. 8, sl. 9). ${ }^{108}$

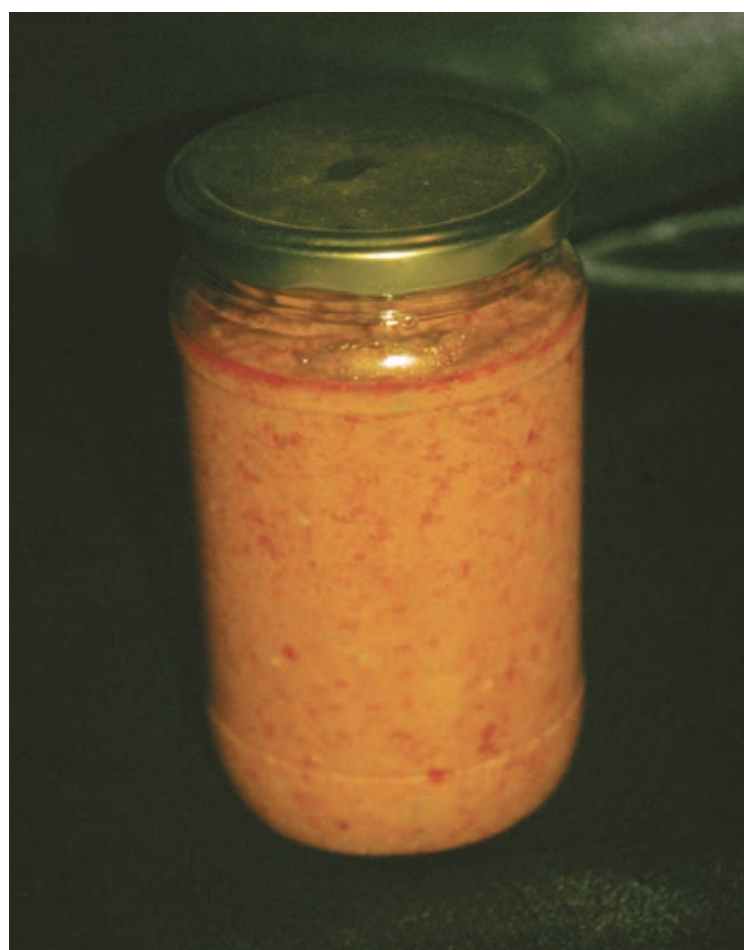

Slika 8: Ajvar, izradila Anka Šojat Colaševa $u$ Francikovcu; snimio Augustin Perić, studeni 2007.

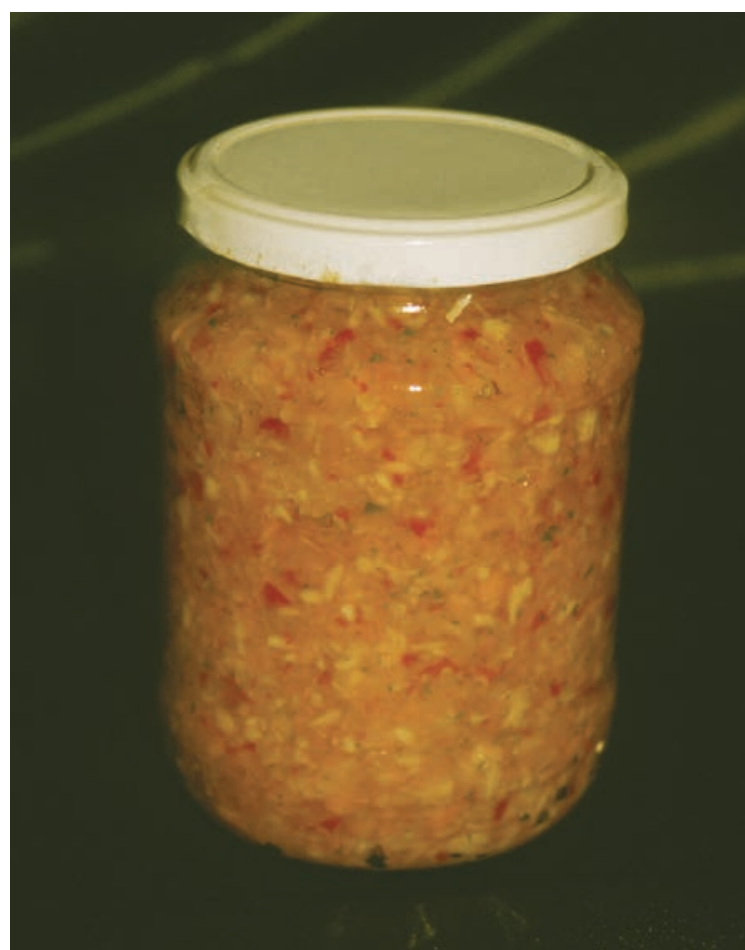

Slika 9: Domaía vegeta, irradila Anka Šojat Colaševa $u$ Francikovcu; snimio Augustin Perić, studeni 2007.

Dio prehrane Krivopućana čine i mahunarke među kojima se ističe grah, pohranjivan u vreće za zimski period. Svi kazivači navode vlastiti uzgoj mahunarki. Izuzetak predstavlja kazivanje Ivice Vukelića Popa iz Rupe prema kojem se grah kupovao sa strane, recimo od ljudi koji su bili srpske nacionalnosti, a zvali smo ih Vlaji. Tamo gore, Prokike, oni su svi bili dobri proizvodači graha. I bili su uvijek na boljim zemljama.

Samoniklo bilje, poput gljiva, nije se koristilo u pripravljanju jela. Uzgoj gljiva na krivoputskom području također nije zabilježen. Kao glavni uzrok nekorištenja gljiva u prehrani navodi se strah od nerazlikovanja otrovnih od jestivih vrsta. Prema kazivanju Anke Šojat Colaševe, kasnih osamdesetih godina prošloga stoljeća počele su se brati gljive, ali većinom u sakupljanje gljiva dolaze iz bližih urbanih središta, primjerice, Senja i Rijeke. Najviše se beru vrganji, sunčanice, pečurke.

Većina kazivača ukazuje na klimu kao glavni razlog zbog kojega se sadio vrlo mali broj voćaka. Škrti kraj, ako ti ne daš zemlji neće ni ona tebi, iskaz je koji potvrđuje osobitosti klime s burom. ${ }^{109}$ Drugi važan

108 Vegeta se radi od zasoljene mljevene mrkve, peršina, korabe, listića od tzv. francuskog peršina. Vegetu su samoinicijativno počele proizvoditi sestre Anke Šojat u Gospiću. Razgovor s kazivačicom je obavljen naknadno u studenom 2007., budući da autorica za vrijeme svojih istraživanja nije razgovarala s Ankom Šojat, koja se proizvodnjom domaćih prehrambenih artikala i skupljanjem i uzgojem ljekovitog bilja bavi od svoje mladosti, intenzivnije u posljednjih desetak godina. Razgovor vodila M. Černelić.

${ }^{109}$ Marko Žuljević Mijatin(a), Žuljevići. 
razlog je ekonomski, koji ukazuje na činjenicu da je u poratnom razdoblju bilo teško nabaviti osnovne namirnice, a i manje se obraćala pozornost na namirnice kao što je voće. Oskudica se naglašava refleksivnim pitanjem: ko je zna za naranču ili jabuku? ${ }^{110}$ Treći se razlog nalazi u objašnjenju Marka Pavelića Mijatinog i Katice Hotlovec koji navode sadnju jasena koji bi donosio veće koristi. Drvo jasena je kvalitetno pa se prodavalo, a voću nije bilo koristi saditi. Svi kazivači navode škrtost kraja prema voćkama, ali i rast divljih kao što su jabuke, kruške i trešnje. Marko Tomljanović Cote iz Šimerića sjeća se kako je 1943. godine svaka kuća dobila po dvije voćke jabuke, te ih danas nazivaju Pavelićeve jabuke. ${ }^{111}$ Svi kazivači navode siromašan poljoprivredan kraj te slabu zastupljenost šljiva: šljivu si pojea na zraku jer bilo je dice (Marko Pavelić Mijatin(a), Žuljevići). Milan Tomljanović Periša iz Zamalića sjeća se nestrpljive djece, među kojima je i sam bio, koja su brala nedozrele i zelene jabuke. Od bobičastog voća skupljale su se: divlje maline, kupine, šipak, šumske jagode, merale (Šolići), trnjule (Podbilo), drinjule (Krivi Put, Mrzli Dol, Veljun). Milan Pavelić Sikirica iz Mrzloga Dola objašnjava kako se radi o crvenim bobicama vrlo slatkoga okusa pri zrenju. Pekmez i džemovi pravili su se od šljiva, i to samo ako je urod bio dobar, što je ovisilo o klimatskim prilikama određene godine, pa se događalo da šljive i po nekoliko godina ne daju plodove. Unazad desetak godina Anka Šojat Colaševa pravi pekmeze i džemove (žele) i od drugih vrsta voća: jabuka, bresaka, marelica, jagoda, od povrća (mrkva, jabuka i buća miješano), kupina i drena. Od voćaka ima samo jedno stablo jabuke i jedno stablo breskve, ostalo voće kupuje. Ponekad priprema i pekmez od šipka, ali samo ako ima vremena brati, u listopadu ili studenom, budući da u ovome kraju šipak kasnije dozrijeva. Anka Šojat Colaševa već nekoliko godina sudjeluje na manifestaciji Jesen u Lici, gdje je 2007. godine dobila 3. nagradu za vlastite proizvode. Tradiciju proizvodnje viševrsnih pekmeza i džemova dijelom je prenijela iz rodne Like, a također je pronalazila recepte u starim knjigama i u Gospodarskom listu (sl.10), (sl. 11). Osim Anke Šojat, proizvodnjom džemova bavila se do nedavno i Anka Prpić iz Šimerića. Ona je imala otvoren vlastiti obrt i svoje je proizvode izlagala na Zagrebačkom velesajmu, manifestaciji "Eko-etno Hrvatska”. (sl. 12). ${ }^{112}$
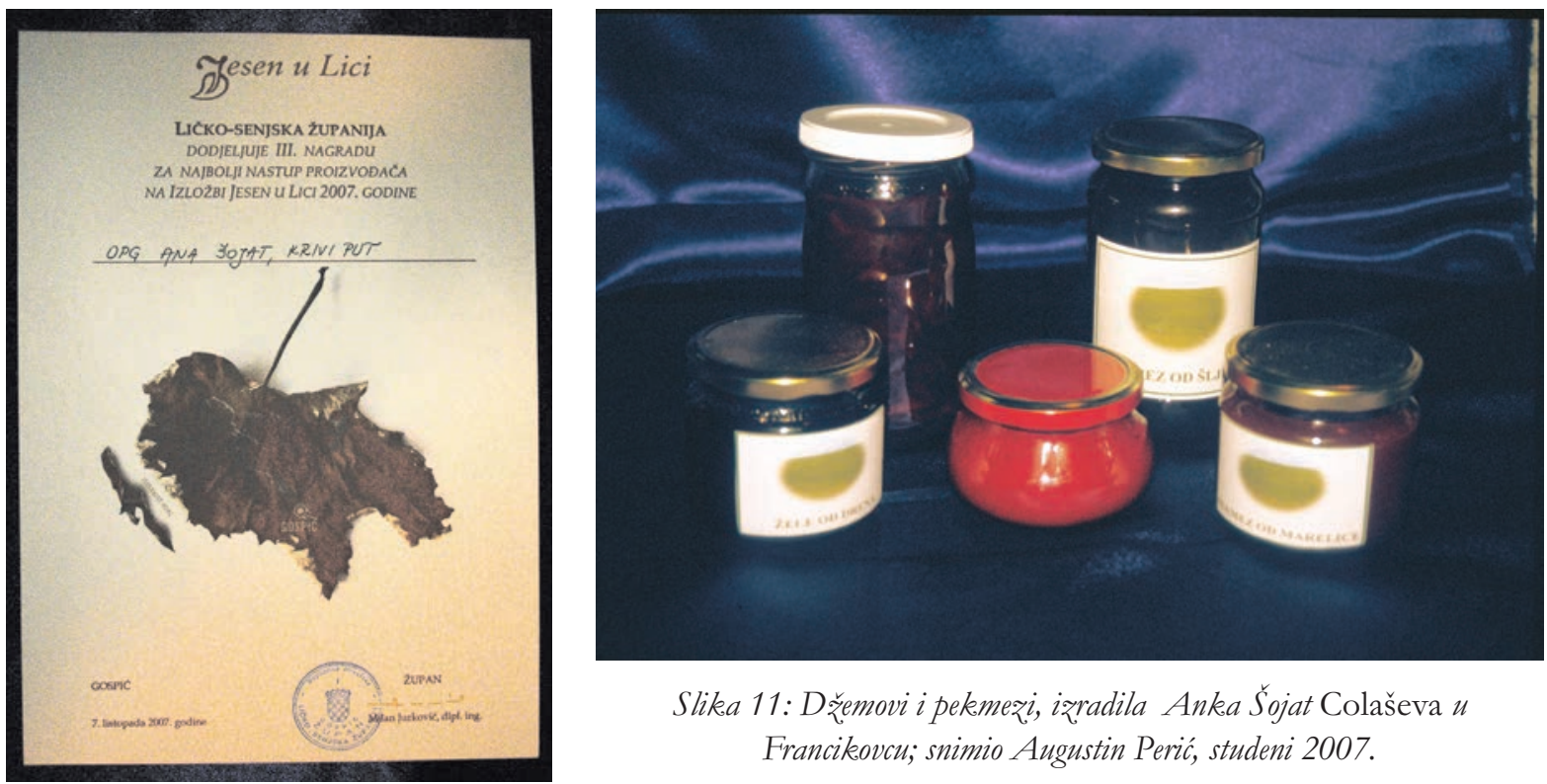

Slika 11: Dřemovi i pekmeži, ižradila Anka Šojat Colaševa u Francikovcu; snimio Augustin Perić, studeni 2007.

Slika 10: Priznanje dodijeljeno na manifestaciji 'Jesen u Lici'; snimio Matija Dronjić, studeni 2007.

110 Marija Tomljanović Čonina, Podbilo.

111 Naziv se odnosi na dr. Antu Pavelića koji je 1941. ustanovio Nezavisnu Državu Hrvatsku. (Usp. Matković 2003:244)

112 Prije nekoliko godina Anka Prpić odselila se u inozemstvo, tako da s njom nisam uspjela razgovarati. 


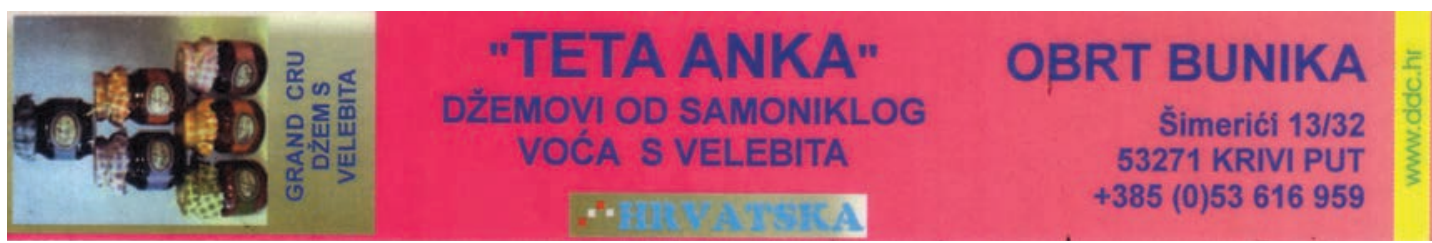

Slika 12: Preslika reklamnog bookmarkera obrta «Teta Anka» koji se dijelio na manifestaciji "Eko-etno Hrvatska", u Zagrebu 2005.

\section{PIĆE}

$\mathrm{O}$ snovno piće bila je voda, te je na cijelom području uočeno postojanje šterni iz kojih se izvlačila. ${ }^{113}$ Vino se pilo u rijetkim prigodama, kao što su blagdani i slavlja, ali najčešće prilikom obavljanja sezonskih poslova, npr. košnja ljeti. Tada bi žene nosile vodu i vino koscima u drvenim žbanjicama (svi lokaliteti), banjicama (Cupići), barićima. Radnici, kosci pili su čisto vino ili razrijeđeno vodom, bevandu, što je ovisilo o vlastitim željama. Ivanka Atalić iz Alana ističe: bevanda, to je po dalmatinskom - njihovo vino $i$ njihov naziv. Žene nisu pile, a ako i jesu nije se blagonaklono gledalo na njih. Crno vino imalo je prednost pred bijelim, koje se rjeđe konzumiralo. Vino se nije pravilo, nego se kupovalo od Bodula, otočana s Raba, Paga i Krka, kao i od Primoraca ili Senjana. Prigode, kao što su Božić, Uskrs, svadba, rođenje djeteta iziskivale su nabavu vina, ali zbog siromaštva to nije bio imperativ. Drugi alkoholni proizvod koji je bilo potrebno imati u kući bila je rakija. ${ }^{114}$ Kao i vino, rakija se nije pravila u vlastitoj proizvodnji, nego se kupovala od Ličana. Oni su pravili šljivovicu, rakiju od šljiva. Katica Hotlovec iz Matić Gaja napominje kako je svaka kuća gledala da ima rakije. Milan Tomljanović Periša iz Zamalića kazuje kako je rakija u kući bila samo za goste, kad bi nas posjetio lugar, žandar onda se to njima točilo. Marko Pavelić Mijatin iz Žuljevića dodaje: da si ima od česa pravit, pravija bi. Osim spomenute śljivovice, u Veljunu i Matić Gaju navodi se i rakija dropovica. Rakija pripravljena od grožđa nabavljala se od Bodula. U Alanu se od malina

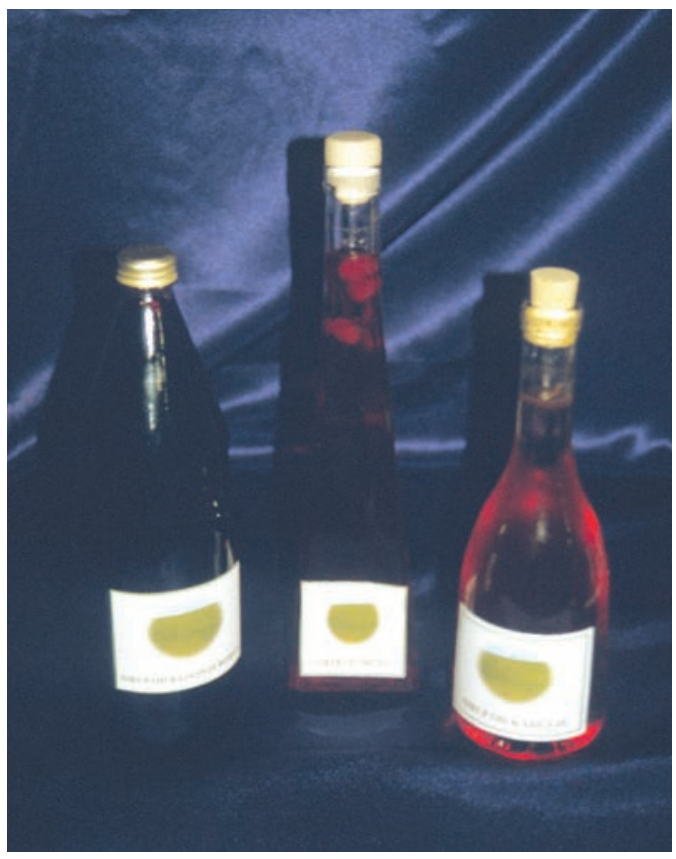

Slike 13: Sokovi i likeri, iæradila Anka Šojat Colaševa u Francikovcu; snimio Augustin Perić, studeni 2007.

113 Detaljnije o opskrbi vodom vidi u D. Birt u prvom svesku monografije, str. 307-319.

114 U Špaljima se ističe kako je svaka deseta kuća imala rakije, a na Krivome Putu kako se malo rakije i držalo. 
pravio sok malinovac. Pripravljanje malinovca potvrđeno je i u Krivome Putu te Mrzlom Dolu. Razlog ne toliko učestalom pravljenju sokova je u količini šećera potrebnoj za proizvodnju, kila šećera na kilu malina ide (Nada Prpić Terezina, Krivi Put). I u Francikovcu se u ranijem razdoblju pravio malinovac. Anka Šojat Colaševa priprema sokove od bazgina cvijeta i bobica te od kupina i drena, od kojih priprema i liker, kao i orahovac od zelenih plodova oraha, koje bere u lipnju (sl. 13).

U Zamaliću i Špaljima napitak poput cherry-brandyja koji su osobito konzumirale žene nazivaju trambuva. ${ }^{115} \mathrm{U}$ Alanu i Krivome Putu navodi se i slatkasto piće pod nazivom šerbet, koje se pravi od meda. ${ }^{116}$ Već je spomenuto kako je kava neizostavan dio jutarnjeg obroka. Prema iskazima svih kazivača, kava je bila namirnica koja se, posebice u ratnom i poratnom razdoblju, teško nabavljala. Kupovala se na deke u zrnju te se zatim pržila i mljela na male mlinove, mlinčiće ili drvene stupice i tučak (Cupići, Veljun). U nedostatku kave koristio se i ječam. Nakon čišćenja, stupanja u stupici i mljevenja, pripremao se na isti način kao i kava. S dodatkom mlijeka spravljala se i bijela kava, koju i danas neki od kazivača rado piju. Dvije vrste kave navode svi kazivači Krivoga Puta: divka i cikorija. Radi se o preuzetim tvorničkim nazivima pakiranja. Među omiljenim napitcima spominju se i čajevi od raznorodnih, uglavnom livadskih trava. ${ }^{117}$ Pravili su se od domaćih trava koje su se nakon skupljanja sušile i spremale za godinu. Konzumirali su se većinom radi sprečavanja bolova, zatim u slučajevima bolesti poput prehlade ili gripe i zbog zdravlja općenito. Od trava, kazivači su istaknuli sljedeće: metvicu, gospinu travu, glog, majčinu dušica i kamilicu. ${ }^{118}$

\section{JELA I NJIHOVO PRIPRAVLJANJE}

P rehrana je sastavljena od već spomenutih važnijih namirnica čije je kombiniranje ponajviše zavisilo o pojedinačnim ukusima. Razlikuju se svakodnevna jela od onih jela pripravljenih za posebne prilike i blagdane. Ipak, neka jela se izdvajaju kao uvrježenija u cijelom području. Jedno od jela čija priprema nije zavisila o godišnjem dobu, dakle jelo se i zimi i ljeti, jest začinjena palenta. To je jelo napravljeno od kukuruznog ili ječmenog brašna s dodatkom putra. Recept koji donosi Marija Tomljanović Čonina iz Podbila upotrebljava se na cijelom području Krivoga Puta. Krumpir se očisti, pa se skuva, dobro se zagnjavi. Onda se brašno ku'ruzno doda i to se sve miša. Na kraju se začini putrom. Uz palentu, moglo se i suhoga sira naribati ozga (Zlata Tomljanović Pešina, Krivi Put). Često se u ječmenu palentu stavljao skuhani krumpir pa bi se dobila krumpirova palenta ili krumpirica koja bi se jela s kiselinom. Marija Prpić Vinina iz Veljuna prisjeća se da je tako spremljeno jelo bilo bog i batina. Zelje i meso jelo je sastavljeno od kiseloga kupusa i suhoga svinjskog mesa. Marko Pavelić Mijatina iz Žuljevića šaljivo dodaje: zelja kiselog i da je svinja zagazila unutra, to je bio božji ručak. Svi su kazivači potvrdili pripravu ovoga jela najmanje jednom tjedno, a nekad i učestalije. Kuhanje ovoga jela ovisilo je o količini kiseloga kupusa, za koju se uvijek trudilo da ga bude dovoljno tijekom cijele godine. Jelo je bilo omiljeno u zimskom periodu, sve do početka ljeta. Osim ovoga jela, s kiselim kupusom jeo se i grah odnosno zelje gra', te domaće tijesto. Kao dodatak grahu jelo se tijesto te kuhani krumpir.

Najjednostavnije i najpoznatije jelo od krumpira su pole ili police. Krumpir ima jaku koru, prema riječima Ivice Vukelića Popa iz Rupe, pa se razreže i zatim istrlja sa solju. Kora ide dole i u pećnicu. Kada požuti izvadiš ga van, malo razrežešs slanine i dodaš luka bijelog. Recept je poznat svim kazivačima s razlikom pečenja u roli, pećnici ili pod pekom. ${ }^{19}$ Krumpir na salatu pravio bi se tako da bi se nakon kuhanja izre-

115 R. Pavelić pod istim nazivom navodi kako je svako domaćinstvo, u slučaju bolesti, prije Drugoga svjetskog rata koristilo nekoliko desetina litara ovoga omamljujućega soka. (1973:179)

116 Detaljnije vidi u prilogu o pčelarstvu Marijete Rajković u prvom svesku Monografije, str. 249-264.

117 Ivan Krmpotić Bokula iz Veljuna navodi kako trideset godina pije isključivo čaj ujutro, umjesto kave.

118 Detaljnije vidi u radu P. Kelemen o narodnoj medicini u ovom svesku Monografije.

119 Ove su razlike uvjetovane vremenom. Nakon rjeđe upotrebe peke, pole su se pravile u češće upotrebljavanim rolama. 
zao, zatim dodala kapula i ulje (Gašpar Butković Rila, Alan). Od krumpira se pravilo i jelo zvano njoki. ${ }^{120}$ Skuhani krumpir stavljao se u smjesu brašna, jaja i vode. Od dobivene smjese prave se okruglice koje se pune šljivama ili pekmezom. Kuhaju se u ključaloj (uzavreloj) slanoj vodi, nakon čega su spremne za posluživanje. Ako se knedlice začine sa putrom nazivaju se njoki začinjeni (Alan). Šljive i pekmez su na ovom području u upotrebi od sedamdesetih godina 20. stoljeća i od tada su njoki u prehrani. Već je spomenuto tijesto kao namirnica u prehrani. Milan Tomljanović Periša iz Zamalića dodaje: a nekad se znalo i kupit tijesto, al obično su to žene zamisile. Imale su kokoši svoje, jaja svoja. Imali smo mi na stolu plahtu jednu i one valjke i to su valjale. I onda se sareže to i domaće tijesto bude. Za juhu sitno (sl. 14), a ovi što smo jedrije pravili to za gra, krumpir i tako. Na području Podbila zabilježen je naziv rizanci ili tisto na suvo. Soparni rizanci su rezanci napravljeni bez jaja. Uspoređujući s učestalijim pripravljanjem instant juhe iz vrećice posljednjeg desetljeća 20. stoljeća, kazivači navode stariji recept priprave ampre juhe. Identičan je na cijelom području: u posudi treba rastopiti porciju masti ili putra kojemu treba dodati brašna, miješati na vatri nekoliko minuta i zatim dodati vodu i mljevenu crvenu papriku. Kad sve prokuha, u zapršku se umiješa juha koja je prethodno skuhana. U Alanu navode da su se u juhu, po potrebi, mogli dodavati i kapanci-smjesa napravljena od brašna i jaja, koja se žlicom kapa u juhu.

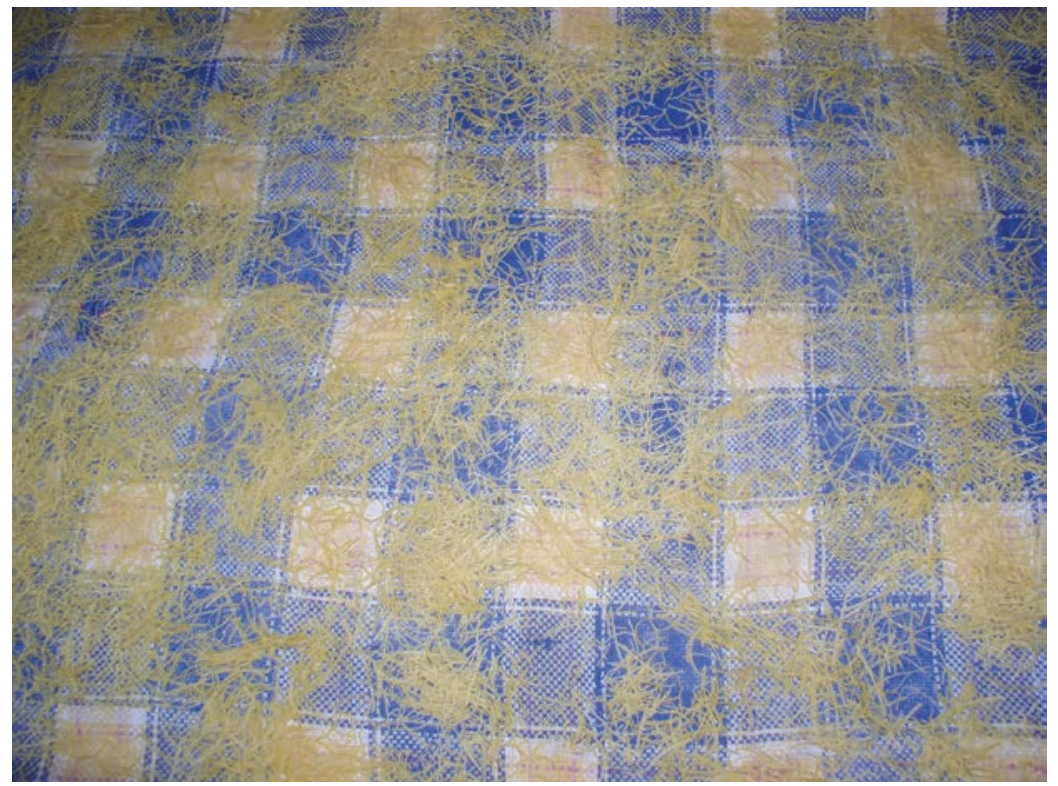

Slika 14 : Rezanci za jubu, ižradila Anka Šolić Tutanova, Šolicí; snimila Marijeta Rajković, lipanj 2006.

U zimskom periodu jela se pretežito sarma, jelo od kiseloga kupusa i mesa. Prema iskazima kazivača, sarma se pravila u svečanijim prigodama, kao što su svatovi. To nije bilo svakodnevno jelo. Za svatove se pripravljala bogatija hrana, kao što su pečenka, odnosno janje na ražnju, rižoto, razne sezonske salate te kokošja juha.

U zimskom periodu pravili su se također i kolači od namirnica pripravljenih za zimnicu. Pekmezača je kolač s pekmezom, a pripravlja se k’a i štrudla. Kolači su se pripravljali i u ostatku godine. Kolač štrudla pravi se od sira, jer je bilo sira, kako navodi Ivanka Atalić Garina iz Alana. Tijesto koje se punilo smjesom sira i jaja pravilo se tako da se prstima razvlačilo preko stola. Vrlo često se štrudla pravila od grušalne. U Žuljevićima kazivači spominju kolače peršule, koji su pojašnjeni riječima Marka Pavelića Mijatinog: kao uštipci današnji, smjesu jaja i brašna stavljate u vruću mast. U Krivome Putu spominju slastice fritule, pripravljane za posebne prigode, najčešće razdoblje poklada te za Čistu srijedu, kada je post (Mara Tomlja-

120 Ivan Vukelić Pop iz Rupe navodi osim naziva njoki i naziv knedle. Deminutiv knedlice u Alanu upotrebljavaju za kuglice, a cijelo jelo nazivaju njoke. 
nović Isanova). Prilikom klanja, dakle u zimskom periodu, za marendu se jela žigerica, odnosno svinjska jetra pripravljana na vrućoj svinjskoj masti ili kupovnome ulju.

Iako je napomenuto kako riba nije bila omiljena prehrambena namirnica, neki kazivači navode kao noviju pojavu pripravljanje ribe bakalar za Badnjak (Podbilo). Eleonora Prpić Lejina iz Veljuna napominje za bakalar: ne sjećam se puno ni mi da smo pravili, ali bilo je neki godina, nije bilo svake. ${ }^{121} \mathrm{Na}$ Badnjak se također pravilo i jelo grah na salatu. U blagdansku hranu ubraja se i spomenuta ćeladija ${ }^{122}$ odnosno hladetina koju svi kazivači navode kao specifično jelo za razdoblje od Božića do Nove godine. Od svinjskih proizvoda za Božić se čuvao već spomenuti brezbuš i mura koja bi se nanovo skuhala. Ivica Vukelić Pop iz Rupe naglašava kako kobasica nije za domaćina, nego za onoga ko dođe kao gost. Suhomesnati proizvodi bili su spremljeni i čuvani za posebne prigode, a među njima su i Božić, Nova godina te različita slavlja. Marko Pavelić Mijatin iz Žuljevića prisjećajući se pečenja kruha za božićno razdoblje šaljivo dodaje: mi smo većinom pravili za sebe, a nismo za Božić.

Prehrana u korizmi te uskrsnome razdoblju nije posebno pripremana: Samo post na Veliki petak i Čistu sridu, a inače druge dane kako si spremija onako si pojea (Marko Pavelić Mijatin, Žuljevići). Ipak, nastojalo se i prehranom obilježiti blagdansko razdoblje. Tako se veliki katolički blagdan Uskrs proslavljao uglavnom obilnijim obrocima i pripremom kruha od brašna i jaja, namirnica koje su davale bogatiji i puniji okus.

U slučaju smrti, pored drugih obveza, vodila se i posebna briga oko pripreme hrane i to za ljude koji bi dolazili izraziti sućut kao i pomoći u prijenosu mrtvaca. ${ }^{123}$ Kod nas se ne zove nikoga, netko je umra i svi ljudi idu. Svi dolaze i to se zove čuvarina (Mara Tomljanović Isanova, Krivi Put). Čuvarina traje cijelu noć i rodbina bdije uz lijes koji je postavljen u kući. Nakon pokopa, obavljalo se podušje. Količina hrane na pogrebu ovisi o imovinskoj situaciji obitelji u kojoj se dogodio smrtni slučaj. Izbor ponuđene hrane također je ovisio i o godišnjem dobu. Na Krivome Putu ističe se kako je zimi bilo teško nositi mrtvaca od kuće do groblja, od upočivala do upočivala, a put bi bio i po nekoliko kilometara. ${ }^{124}$ Tada bi se pripremilo janje na ražnju i rižot, a sve kako bi ljudi imali snage. Nudilo se piće, najčešće rakija. Milan Krmpotić Zekonja iz Veljuna ističe kako se u posljednje vrijeme prije sprovoda svatko u svojoj kući najede. U Mrzlom Dolu kazivači se sjećaju kako se početkom 20. stoljeća: sprovod nije vozija, mrtvac se nosija odavde u Krivi Put, do crkve. Dva ona koca, zavežu one koce i na njemu, to se zvala onda škrinja, danas zovu sanduk, i zavežu $i$ na rame, dva i dva, ja i vi tu, vas dvoje. Kad se umorimo, drugi. ${ }^{125}$

Rođenje djeteta obilježavalo se u obitelji koja je dobila prinovu, a slavlje je najčešće kratko trajalo ponajviše zbog količine posla. Posebno je bilo značajno napraviti juhu od starije kokoši, a sve kako bi se rodilji povratila snaga. Uvriježeno je mišljenje kako kokošja juha daje snagu za brži oporavak. Nastojalo se rodilji također donijeti hranu bogatiju vitaminima. Posebna prehrana za trudnice nije se pripravljala, većinom se jelo šta je pasalo.

\footnotetext{
21 Za ovaj podatak zahvaljujem kolegici Aleksandri Vlatković koja je razgovarala s Eleonorom Prpić Lejinom.

122 Priprava ćeladije opisana je pod naslovom Meso i mesni proizvodi.

123 Ispitivanje o prehrambenim navikama u smrtnim slučajevima nije provedeno kod svih navedenih kazivača.

124 Upočivala su mjesta gdje bi se trebalo otpočinuti od puta te se zamijeniti nosači mrtvačkoga sanduka.

125 Zahvaljujem Sanji Lončar i Petri Kelemen na ustupljenim podacima.
} 


\section{POSUDE I PRIBOR ZA KUHANJE ${ }^{126}$}

$\mathrm{N}$ abava posuđa, padela (zdjela), peka te drvenih stapova i drugoga pribora za kuhanje obavljala se na sajmovima u Lici. Marko Tomljanović Cote iz Šimerića sjeća se kako se ponašalo za stolom. Opisujući oskudicu u prehrani i namirnicama on navodi: Oni su svi dobili jest u jednoj padelici. Ja nisam jeo na takav način. Al' bilo je recimo, svi su jeli izjedne padele, žlice su bile drvene, da se ne mogu poubijati (smijeh). Jer da su imali ove željezne to bi bilo glava razbiti' i očiju vani (smijeh). Drvene su bile, da, sirotinja je bila. Pere Tomljanović Rambula iz Tomića sjeća se kako su njegovi stari svi iz jedne posude jeli, pa čak i drvene žlice bile. Katica Hotlovec iz Matić Gaja također potvrđuje kako se, dok je bila mlada, prije Drugoga svjetskog rata jelo iz jedne posude, ali ističe kako njezina obitelj to nije prakticirala. Ivica Vukelić Pop iz Rupe sjeća se komoštri od željeza koje su visjele iznad otvorenoga ognjišta (sl. 15a, b). Na njima je visio lonac (kaštrola) u kojemu se pravila palenta (sl 16).

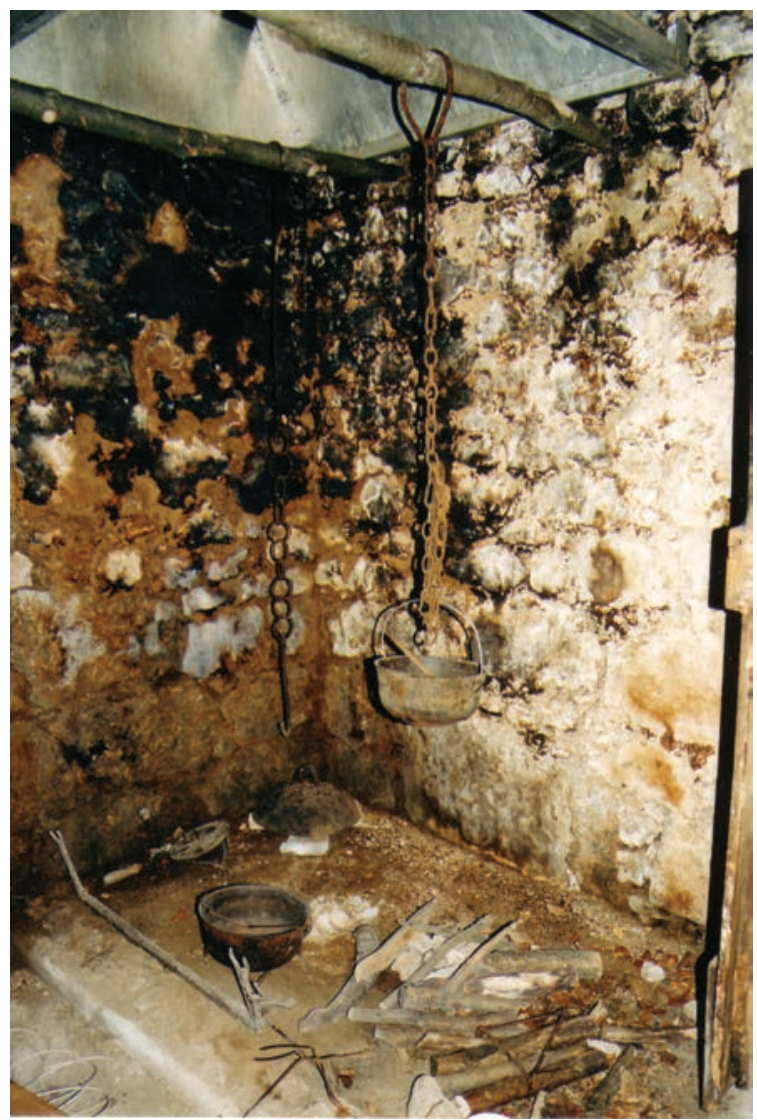

Slika 15a: Otvoreno ognjište u Cupicima, vlasnik otac Milana Tomljanovića Ivića; snimio Augustin Perić, lipanj 2003.

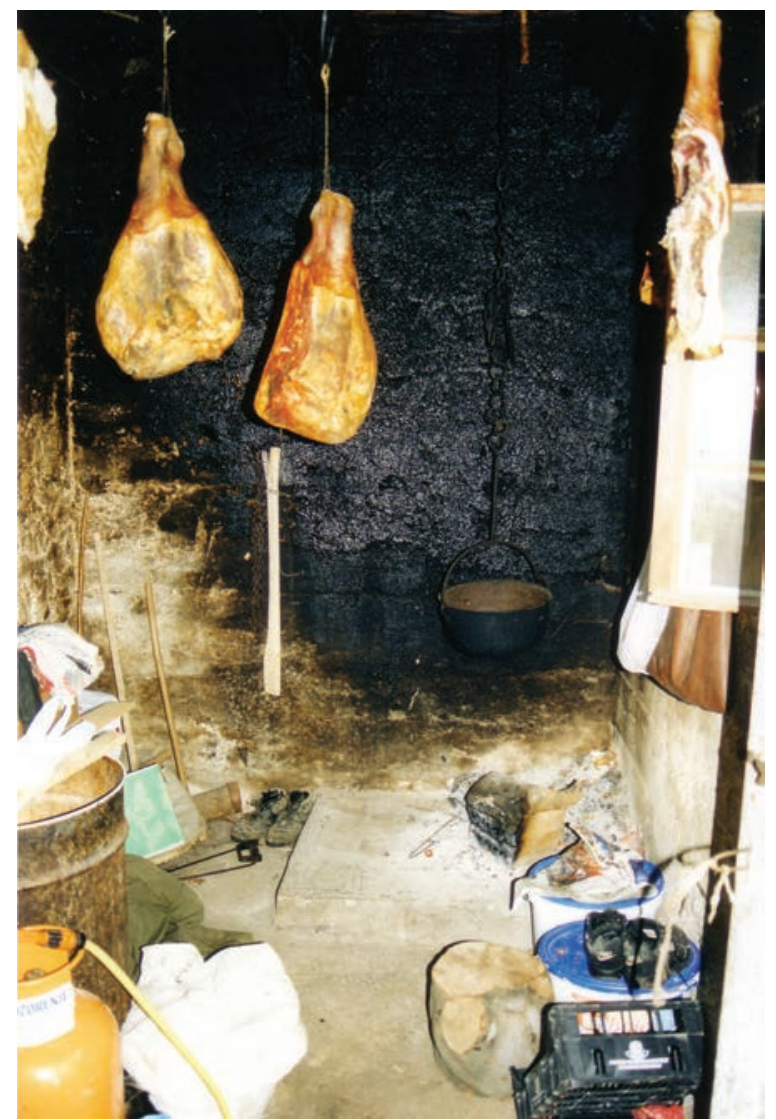

Slika 15b: Otvoreno ognjište u bajti, u funkciji spremista; snimio Augustin Peric, lipanj 2003.

$\overline{126}$ Cjelina o posuđu nije detaljno ni zasebno ispitivana nego su podaci prikupljeni kroz građu o namirnicama, jelima i općenito prehrani Krivopućana te su kao takvi izdvojeni u ovom odlomku. Svakako da bi se detaljnijim ispitivanjem prikupili relevantniji podaci. 


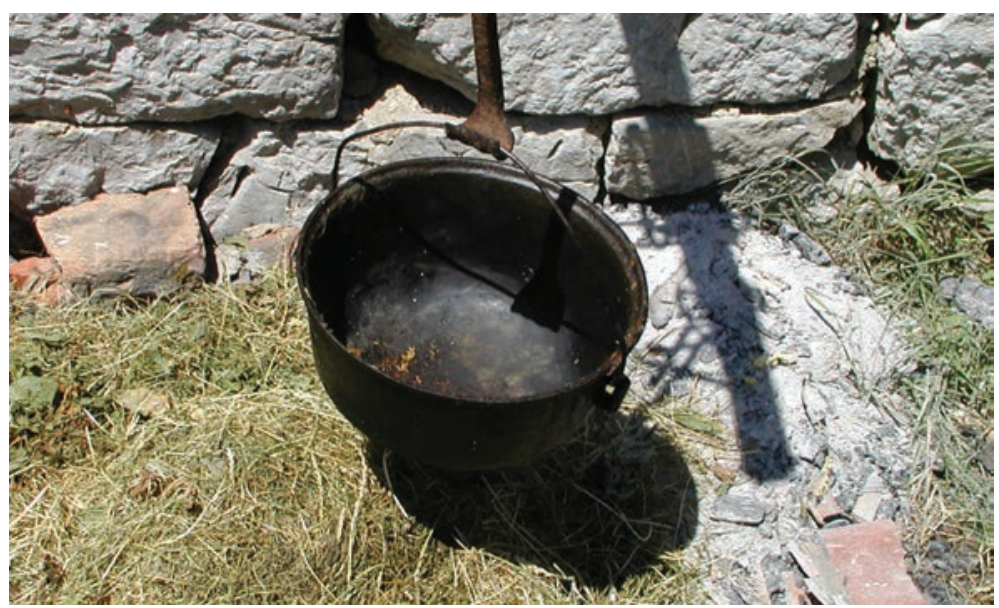

Slika 16: Kaštrola za kubanje palente na otvorenom ognjištu, vlasnik Milan Tomljanović Kanada; snimila Jasmina Jurkovic lipanj 2003.

Tome Špalj Cucin iz Špalja sjeća se iz mladosti: prije su vam imali zemljene bukarice, to je bio malo uže gore, kao kruška, a to se zvala žara, pa se mećalo i maslac. I onako ciglaste boje i bile su isto i padele zemljene gdje se kuhalo mlijeko, ali je to mlijeko bilo ukusnije nego u ovim sudovima. A to su vam pravili pećari, oni su dolazili i prodavali po selima. Onda su još fino tankom žicom veži da se ne rasuje, jer je to ipak zemlja, a moglo se i kuhat u tome. Kazivanje se odnosi na kraj tridesetih godina 20. stoljeća.

Navedeni drveni stapovi i mećaje izrađivali su se u mjestu Kutarevo najčešće od jelovog drveta. Jelovina se kao materijal koristila i u izradi drugih predmeta, poput pribora za jelo i kuhanje, naćvi (korita za mijesiti kruh), žbanjica i drugo.

Piće, uglavnom voda, držalo se u drvenim žbanjicama, barilcima, burilima i bocunima (staklenim opletenim bocama (sl. 17). Stanovništvo ovoga područja pamti slabiju uporabu staklenoga posuđa koje uostalom, kako sami ističu, i nije bilo dostupno ruralnome stanovništvu sve do kraja pedesetih godina 20. stoljeća.

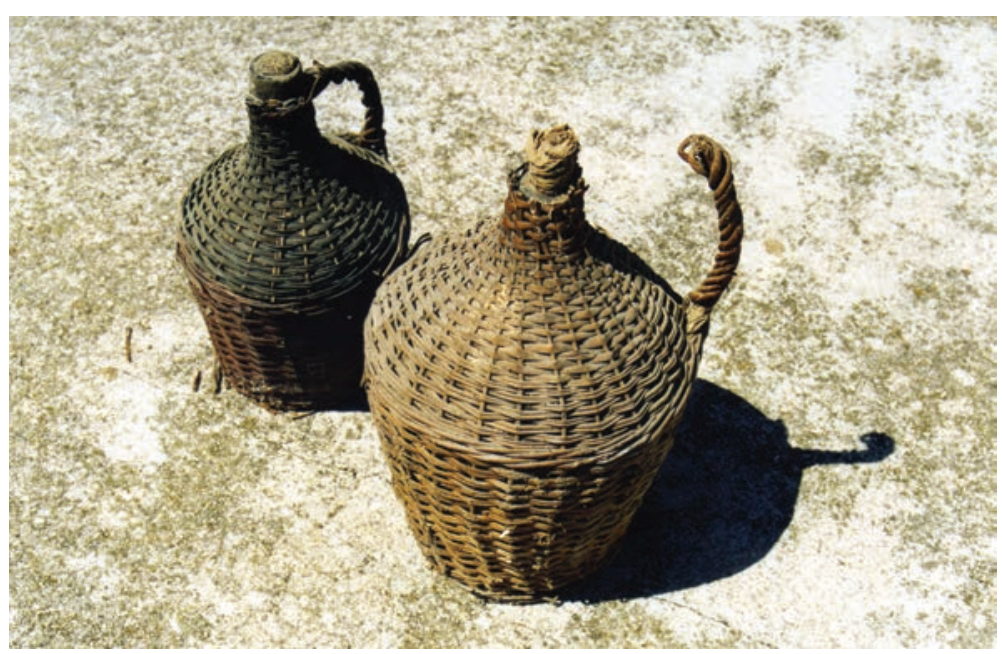

Slika 17: Bocuni za čuvanje vode ili vina; snimio Augustin Peric, lipanj 2004. 


\section{DANAŠNJA PREHRANA I GOSTOPRIMSTVO PRIMORSKIH BUNJEVACA}

$\mathrm{D}$ anašnja prehrana Krivopućana obiluje raznim prehrambenim artiklima. Razlog tome je dostupnost namirnica u trgovinama kao i učestaliji odlasci u Senj. To čini glavnu razliku u odnosu na prehranu do sedamdesetih godina 20. stoljeća. Međutim, snažniji argument u vrednovanju prehrane kroz opreku nekada i danas, za predstavnike primorsko-bunjevačke skupine je kvaliteta namirnica i time općenito prehrane. Tako pripadnici ove skupine smatraju: Zdravije je bilo jel vi ste jeli sve ono što ste sami proizveli; ${ }^{127}$ zdrava hrana $i$ zdravi ljudi i zdrav zrak. Sve zdravo bilo; ${ }^{128}$ ono sto bi sami proizveli, to smo i pojeli; ${ }^{129}$ prije, a rečemo sve je bilo domaće, sve prirodno iz vrta, a sad svega, samo sve je otrov. ${ }^{130}$ Stočarstvo koje počiva prvenstveno na uzgoju ovaca, a nešto manje krava, danas je manje zastupljeno, ali ne i potpuno zaboravljeno. Kao jedan od načina privređivanja žene na Krivome Putu i danas prave sir škripavac. Koriste uglavnom kravlje mlijeko jer napominju da je ovce teže musti. Proizvodnja sira dostatna je za vlastite potrebe ili unaprijed dogovorene narudžbe.

Krumpir u današnjoj prehrani predstavlja njezin najznačajniji segment, a Krivopućani naglašavaju $i$ sad nam je krumpir glavna hrana. Luka Krmpotić Brnde iz Veljuna obrazlaže: gojimo krumpir i danas, mi puno trošimo. Njegova žena Mara ipak upozorava na lošiju kvalitetu: sad je nekako voden krumpir.

Uvriježeno mišljenje kako je kupovni, bijeli kruh pokazatelj ekonomske stabilnosti, naspram domaćega kruha koji je za ruralnu sredinu, iskazuje Katica Hotlovec iz Matić Gaja. Ona kaže: $A$ za džabe sad jedemo bijeli kruh, a nije blagoslova, nije zadovoljstva. U vrijeme ispitivanja zamijećeno je kako se kruh peče u roli odnosno šparetu. Kruh iz špareta danas priprema i Nada Prpić Terezina iz Krivoga Puta, iako živi u neposrednoj blizini krivoputske trgovine. Njoj je to ukusniji kruh. Priprava kruha pod pekom i otvorenim ognjištem prestala je ubrzo nakon Drugoga svjetskog rata. U vrijeme ispitivanja kazivači su se sa nostalgijom prisjećali mirisa i okusa toga "savršenoga” kruha: Pod pekom kruh je najukusniji. ${ }^{131}$ Takav izražajan stav o ukusnijoj hrani zamijećen je i tijekom ispitivanja drugih tema. Palentu kad je gotova prelijete s maslacem i malo kiseline. Danas toga nema, maslac kad se otopi ima taj svoj jedan talog koji je super, e a toga nema. Margarin ili ovo što je kupovno, to nije to. Tim riječima Marko Pavelić Mijatin iz Žuljevića nastoji pojasniti kvalitetu nekadašnjega mlijeka i maslaca. Ovo mlijeko današnje, to nema skorupa, jako je rijetko. A ono je svu kaloriju imalo, masnoću. ${ }^{132}$ Prisjećajući se spravljanja jela na žlicu, Pere Tomljanović Rambula iz Tomića kazuje koliko je hrana bila ukusna: S putrom se začini ćušpajz od koprive i to bude milina. Zlata Tomljanović Pešina iz Krivoga Puta kazuje kako krumpirovu palentu još i danas kuha, s izuzetkom da joj kći iz Zagreba donosi domaći putar. Ona ukazuje na prehrambenu vrijednost palente koju uočavaju i današnji stručnjaci. Mogo si stopit putar, pa s tom palentom i kiselinu dodati, i to ti je bila večera za prste... sjeća se Ivica Vukelić Pop iz Rupe.

U razdoblju posljednjega desetljeća 20. stoljeća više se obraća pozornost nutricionističkoj vrijednosti ribe, iako su prisutne uvriježene nevjerice u vezi kostiju i pripreme. Tjedni obroci mesa danas nisu regulirani nepisanim pravilom o četvrtku i nedjelji. Meso se, prema potrebi, jede više puta tjedno. Nekada obavezno klanje danas nije učestala pojava na Krivome Putu. Danas se stanovništvo opskrbljuje u senjskim mesnicama, unatoč pojedinačnim željama poput one Zlate Tomljanović Pešine iz Krivoga Puta: I danas vičem da mi je jedna žaklja.

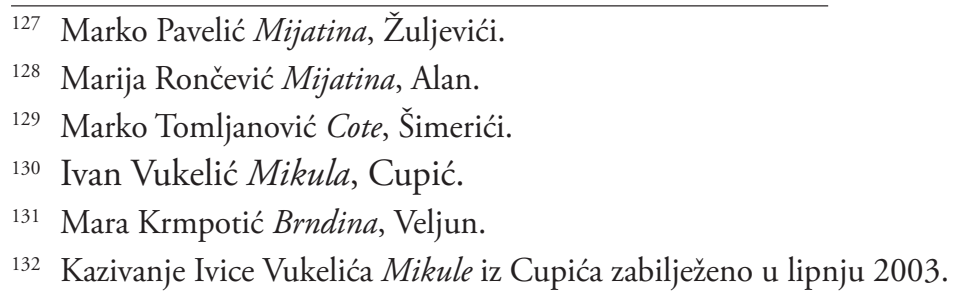


Bilo je rakije u kući, ali to je bilo za goste i kad bi došao lugar, žandar onda se to njima točilo, a inače mi domaći ljudi nismo nikad to. Ovakav stav u ophođenju prema gostima istaknuo je Milan Tomljanović Periša iz Zamalića, a potvrđen je i kod drugih primorskih Bunjevaca. ${ }^{133} \mathrm{O}$ posjetama lugara ili žandara Luka Krmpotić Brnde iz Veljuna, donosi sjećanje: Mi smo, kako bi vam reka, malo komotnije živjeli. Onda ispeci, nareži, počasti ga, a onda si se zalago da ga malo ukrotiš. Marko Tomljanović Cote iz Šimerića svojim kazivanjem upotpunjuje: Pršut se čuvao za ljeto, kad se radilo, košnja pa ti obično treba netko sa strane da ti pomogne i čuvalo se za te radnike.

\section{ZAKLJUČAK}

Drehrana ima osobito važnu ulogu u društvenome životu. Zajednički obroci predstavljaju središte društvenih
odnosa (Visočnik 2004:22). Milan Krmpotić Zekonja iz Veljuna sjeća se: nije bilo tko gdje sjedne, stariji su oko stola, a dica su imala onako malu stoličicu, te ima majka metne onu zdjelu i onda svi zajedno jedu. Položaj ukućana za stolom u bitnome se promijenio tijekom godina. Sjećanja kazivača potvrđuju istaknuti patrijarhalni stav te podređenost žena prilikom objedovanja. ${ }^{134}$ Vrlo česti opisi rasporeda sjedenja za stolom uključuju razmatranje kroz vremenske odrednice kako je bilo nekada i kako je danas (u vremenu ispitivanja).

Prehrana krivoputskoga područja zavisila je o gospodarskim mogućnostima kraja. Oslanjanje na zemlju i vlastite resurse rezultiralo je spravljanjem jela pomoću kojih se stanovništvo definiralo prema drugim etničkim skupinama i područjima. Unatoč prepoznatljivosti određenih jela, stanovništvo kao „svoje“ jelo navodi sir škripavac, meso $i$ zelje, zatim pole, krvave kobasice, mure i danke, kiselinu. Osobitosti u prehrani, karakteristična jela te izostavljanje ribe i morskih plodova predstavljaju markere Krivopućana kao dijela primorsko-bunjevačke skupine. Objektivni i subjektivni faktori skupine utječu na to koje će osobitosti biti presudne za proces autoidentifikacije, odnosno značajne u "procesu određivanja jednakosti s pripadnicima svoje zajednice ("mi”) i razlikovanja od pripadnika drugih zajednica ("oni”)". ${ }^{135}$ Specifični prehrambeni artikli predstavljaju razlikovne osnove u odnosu na druge susjedne skupine, u prvom redu građane Senja. Zajedničke karakteristike u prehrambenim navikama Krivopućana i druge susjedne skupine, Ličana osobito su uočljive u monografijama o Kompolju i Ivčević Kosi.

Važnost prehrambenih navika u društvenome aspektu trebala bi se posebno promatrati. Time se prvenstveno misli na položaj članova obitelji, ali i gostiju prilikom objedovanja. ${ }^{136}$ Uz postojeće, ali i ovim terenom prikupljene podatke to ostaje zadatkom budućih radova. U radu se nastojalo podatke prikazati kronološki, u vremenskom presjeku. Time su lakše uočljive promjene i prilagodbe nastale u novije vrijeme. Tako se danas više ne mete putar i rijetko se pravi kiselina. Mlijeko se prodaje mljekarama ili koristi za vlastitu proizvodnju sira škripavca. Također, stanovništvo ovoga kraja, većinom starije životne dobi, ne kolje i ne pravi specifične svinjske suhomesnate proizvode jer se mogu kupiti u trgovinama u manjim, dostatnim količinama za njihove potrebe.

Kod svih kazivača istaknuto je stajalište o siromašnom kraju te, uslijed toga, neimaštini u namirnicama i nemaštovitosti u prehrani. Ova sinteza građe pokazuje suprotno od takvog uvriježenoga stajališta domaćega stanovništva. Kroz prikaz prikupljenih podataka mogu se iščitati osobitosti u prehrani Krivopućana.

133 Gostoprimstvo primorskih Bunjevaca snažno se osjetilo prilikom dolaska na teren. Iako smo imali osiguranu hranu u Senju, teško je bilo isprikom odbiti ponuđene obroke, pa su tako neki istraživači ručali i po tri puta kako ne bi uvrijedili domaćine. Kako sam ispitivala specifičnu temu, imala sam prilike degustirati neke od proizvoda o kojima sam ispitivala, u prvom redu to je bio škripavac.

134 M. Rajković pisala je o položaju žene za stolom na području Senjskog bila koje je također naseljeno bunjevačkim stanovništvom: (2003).

135 J. Grbić 1998: 183.

136 O položaju žene za stolom sažeto je pisala i tek dotakla temu ponašanja za stolom, Marijeta Rajković u radu "Život žene u selima Senjskog bila", Senjski zbornik 30, 2003, 539-586. 
Analiza podataka ukazala je i na to kako pripadnici ove skupine valoriziraju današnju prehranu uspoređujući je s onom nekada. Unatoč ekonomskoj nestabilnosti, ističe se nekadašnji zdrav način prehrane koji je, prema mišljenju kazivača, u današnjoj prehrani slabo zastupljen. Zbog sve većeg značenja svjetskog turističkog opredjeljenja za zdravu i domaću hranu, današnja prehrana nastoji objediniti namirnice i jela tradicionalnih kuhinja. Sustavna terenska istraživanja tradicijske prehrane na području Krivoga Puta svakako pridonose takvim nastojanjima.

\section{LITERATURA I IZVORI:}

ANDRIĆ, Jasna (2003): Domaći sir i njegove raznolikosti u Hrvatskoj, u: Sir. Tradicija i običaj, Pučko otvoreno učilište, Zagreb, 15-34.

ARALICA, Višeslav (2000): Gospodarstvo primorskih Bunjevaca, Senjski zbornik, 27, 227-234, Senj.

BROMBERGER, Christian, Pierre CENTHIORES, Gerard COLLOMB (2002): Između lokalnog i globalnog: Figure identiteta, u: ur. Martine Segalen: Drugi i sličan. Pogled na etnologiju suvremenih društava, Naklada Jesenski i Turk, Zagreb, 177-189.

ČAPO ŽMEGAČ, Jasna (1997): Hrvatski uskrsni običaji, Golden marketing. Zagreb.

ČERNELIĆ, Milana (2000): Dvije zadružne obitelji na području Krivoga puta, Senjski zbornik, 27, Senj, 199-216.

ČERNELIĆ, Milana (2003): Istraživanje tradicijske baštine, identiteta i etnogeneze primorskih Bunjevaca, Senjski zbornik, 30, Senj, 407-424.

FRIŠČIĆ, Marija (2000): Teme iz materijalne i duhovne kulture primorskih Bunjevaca, Senjski zbornik, 27:235-240, Senj.

GRBIĆ, Jadranka (1994): Identitet, jezik i razvoj-istraživanje o povezanosti etniciteta i jezika na primjeru hrvatske nacionalne manjine u Madarskoj, Zagreb.

GRBIĆ, Jadranka (1998): Jezik i govor kao komponente pripadnosti zajednici (ogled o jeziku i identitetu), u: ur. Ružica ČIČAK-CHAND i Josip KUMPES, Etničnost, nacija, identitet: Hrvatska i Europa, Zagreb, 181-189.

GRČEVIĆ, Jure (obradio i dovršio Milan KRANJČEVIĆ) (2000): Kompolje, narodni život i običaji, Katedra Čakavskog sabora pokrajine Gacke, Kompolje.

HEĆIMOVIĆ-SESELJA, Mara (1985): Tradicijski život i kultura ličkoga sela Ivčević Kosa, Zagreb.

JAPUNČIĆ, Mile (2000): Lovinački kraj: vrijeme i ljudi, Zagreb.

KADIĆ, Marko (1976): Svinjokolja u Slavoniji, u: Đakovački vezovi, Jubilarna Revija 1967-1976, 48-49, Đakovo.

MENNELI, Stephen, Anne MURCOTT, Anneke H. Van OTTERLOO (1998): Prehrana i kultura; Sociologija hrane, Naklada Jesenski i Turk, Hrvatsko sociološko društvo, Zagreb.

MATKOVIĆ, Hrvoje (2003): Povijest Jugoslavije, Zagreb.

MURAJ, Aleksandra (1998): Prehrana, u: Etnografija, Svagdan i blagdan hrvatskoga puka, Matica hrvatska, 101-108, Zagreb.

PAVELIĆ, Rikard (1973): Bunjevci, Zagreb.

RAJKOVIĆ, Marijeta (2003): Život žene u selima Senjskog bila, Senjski zbornik, 30, 539-586, Senj.

RAJKOVIĆ, Marijeta (2008): Gospodarstvo, u: Živjeti na Krivom Putu. Etnološko - povijesna monografija o primorskim Bunjevcima, svezak I, ur. M. Černelić, M. Rajković, T. Rubić, Zagreb, 157- 278.

ŠKRBIĆ-ALEMPIJEVIĆ, Nevena (2003): Prilozi poznavanju primorskog-bunjevačkog identiteta, Senjski zbornik, 30: 425-444, Senj.

Upitnice Etnološkog atlasa, Svezak 2, teme od 62 do 71, te 74, Fd 241/610, Arhiv Odsjeka za etnologiju i kulturnu antropologiju, Filozofski fakultet Sveučilišta u Zagrebu.

VISOČNIK, Nataša (2004): Hrana i identitet u Japanu, u: Etnološka istraživanja 10, Zagreb, 19-28. 